\title{
Evaluasi Pener apan dan Pencapaian Standar Pelayanan Minimal pada Kab/Kota di Provinsi Kalimantan Timur
}

\author{
Irwan Gani \\ Fakultas Ekonomi dan Bisnis Universitas Mulawarman, Indonesia \\ E-mail: irwan.gani@feb.unmul.ac.id
}

\begin{abstract}
Abstrak
Tujuan dari penelitian ini adalah Untuk mengetahui kendala dan permasalahan yang dihadapi oleh Kabupaten/Kota di Provinsi Kalimantan Timur dalam pencapaian dan penerapan SPM. Adapun Fokus penelitian ini adalah penerapan dan pencapaian Standar Pelayanan Minimal (SPM) di Provinsi Kalimantan Timur. Pemerintah daerah wajib memiliki SPM dalam penyelenggaraan pelayanan publik termasuk diantaranya Pemerintah Kota Balikpapan. Dalam UU Pemda terbaru, terdapat 6 (enam) bidang pelayanan dasar yang wajib memiliki SPM yaitu bidang pendidikan, bidang kesehatan, bidang Ketentraman, Ketertiban Umum dan Perlindungan masyarakat, bidang Sosial, bidang pekerjaan umum dan penataan ruang dan bidang perumahan rakyat.
\end{abstract}

Kata Kunci: Standar Pelayanan Minimal

\section{Evaluation of Implementation and Achievement of Minimum Service Standards at Regency/City in East Kalimantan Province}

\begin{abstract}
The purpose of this research is to know the obstacles and problems faced by the Regency / City in East Kalimantan Province in the achievement and implementation of MSS. The focus of this research is the implementation and achievement of Minimum Service Standards (SPM) in East Kalimantan Province. Local government must have SPM in the implementation of public service including Balikpapan City Government. In the latest Regional Government Law, there are 6 (six) basic service areas which must have SPM namely education, health field, peace, public order and community protection, social affairs, public works and spatial arrangement and public housing field.
\end{abstract}

Keywords: Minimum Service Standards 


\section{PENDAHULUAN}

Pasal 9 Undang-Undang Nomor 23 Tahun 2014 tentang Pemerintahan Daerah sebagaimana terakhir kalinya diubah dengan Undang-Undang Nomor 9 Tahun 2015 tentang Perubahan Kedua Atas Undang-Undang Nomor 23 Tahun 2014 tentang Pemerintahan Daerah (selanjutnya akan ditulis UU Pemda), menyebutkan bahwa Urusan Pemerintahan terdiri atas urusan pemerintahan absolut, urusan pemerintahan konkuren, dan urusan pemerintahan umum. Urusan pemerintahan konkuren yang diserahkan ke Daerah menjadi dasar pelaksanaan Otonomi Daerah.

Pasal 11 UU Pemda melanjutkan bahwa urusan pemerintahan konkuren yang menjadi kewenangan daerah terdiri atas urusan pemerintahan wajib dan urusan pemerintahan pilihan. Adapun urusan Pemerintahan wajib terdiri atas urusan pemerintahan yang berkaitan dengan pelayanan dasar dan urusan pemerintahan yang tidak berkaitan dengan pelayanan dasar. Dijelaskan lagi bahwa urusan pemerintahan wajib yang berkaitan dengan pelayanan dasar adalah urusan pemerintahan wajib yang sebagian substansinya merupakan pelayanan dasar.

Selanjutnya pemahaman diarahkan pada ketentuan Pasal 12 ayat (1) UU Pemda yang menyebutkan bahwa urusan pemerintahan wajib yang berkaitan dengan pelayanan dasar meliputi: a. pendidikan; b. kesehatan; c. pekerjaan umum dan penataan ruang; d. perumahan rakyat dan kawasan permukiman; e. ketenteraman, ketertiban umum, dan pelindungan masyarakat; dan f. sosial.

Dalam rangka menjalankan urusan pemerintahan wajib yang berkaitan dengan pelayanan dasar, penyelenggara pemerintahan daerah wajib memberikan prioritas pelaksanaan yang didasarkan pada standar pelayanan minimal (SPM) yang ditetapkan oleh pemerintah pusat. Ketentuan tersebut tercantum pada Pasal 18 ayat (1), ayat (2), dan ayat (3) UU Pemda. Ayat (1) berbunyi "Penyelenggara Pemerintahan Daerah memprioritaskan pelaksanaan Urusan Pemerintahan Wajib yang berkaitan dengan Pelayanan Dasar sebagaimana dimaksud dalam Pasal 11 ayat (3)", dilanjutkan pada ayat (2) "Pelaksanaan Pelayanan Dasar pada Urusan Pemerintahan Wajib yang berkaitan dengan Pelayanan Dasar sebagaimana dimaksud pada ayat (1) berpedoman pada standar pelayanan minimal yang ditetapkan oleh Pemerintah Pusat", dan pada ayat (3) disebutkan bahwa "Ketentuan lebih lanjut mengenai standar pelayanan minimal diatur dengan peraturan pemerintah".

Berdasarkan Pasal 1 angka 17 UU Pemda, SPM adalah ketentuan mengenai jenis dan mutu Pelayanan Dasar yang merupakan Urusan Pemerintahan Wajib yang berhak diperoleh setiap warga negara secara minimal. Adapun untuk ketentuan lebih lanjut mengenai SPM, sampai dengan saat penelitian ini dibuat (Mei 2016) belum diterbitkan peraturan pemerintahnya, sehingga masih merujuk pada Peraturan Pemerintah Republik Indonesia Nomor 65 Tahun 2005 tentang Pedoman Penyusunan Dan Penerapan Standar Pelayanan Minimal (selanjutnya akan ditulis PP Nomor 65/2005). Perujukan tersebut sangat dimungkinkan berdasarkan ketentuan Pasal 408 UU Pemda yang menyatakan "Pada saat Undang-Undang ini mulai berlaku, semua peraturan perundang-undangan yang berkaitan dengan penyelenggaraan Pemerintahan Daerah dinyatakan masih tetap berlaku sepanjang belum diganti dan tidak bertentangan dengan ketentuan dalam Undang-Undang ini”.

Penting untuk dipahami bahwa dalam Pasal 3 ayat (1) dan ayat (2) PP Nomor 65/2005, disebutkan bahwa SPM disusun sebagai alat Pemerintah dan Pemerintahan Daerah untuk menjamin akses dan mutu pelayanan dasar kepada masyarakat secara merata dalam rangka penyelenggaraan urusan wajib dan SPM ditetapkan oleh Pemerintah dan diberlakukan untuk seluruh Pemerintahan Daerah Provinsi dan Pemerintahan Daerah Kabupaten/Kota. Dilanjutkan dalam Pasal 9 PP Nomor 65/2005 bahwa pemerintahan daerah menerapkan SPM sesuai dengan ketentuan yang diatur dalam Peraturan Menteri dan menjadi salah satu acuan bagi pemerintahan daerah untuk menyusun perencanaan pencapaian SPM yang memuat target tahunan. Peraturan Menteri tersebut juga digunakan oleh pemerintahan daerah untuk dan penganggaran penyelenggaraan Pemerintahan Daerah. Untuk kemudian rencana pencapaian SPM dituangkan dalam Rencana Pembangunan Jangka Menengah Daerah (RPJMD) dan Rencana Strategi Satuan Kerja Perangkat Daerah (Renstra SKPD). Adapun target tahunan pencapaian SPM dituangkan ke dalam Rencana Kerja Pemerintah Daerah (RKPD), Rencana Kerja Satuan Kerja Perangkat Daerah (Renja SKPD), Kebijakan Umum Anggaran (KUA), Rencana Kerja dan Anggaran Satuan Kerja Perangkat Daerah (RKA-SKPD) sesuai klasifikasi belanja daerah dengan mempertimbangkan kemampuan keuangan daerah. 
Keberadaan PP Nomor 65/2005 dikuatkan lagi dengan terbitnya Peraturan Menteri Dalam Negeri Nomor 6 Tahun 2007 tentang Petunjuk Teknis Penyusunan Dan Penetapan Standar Pelayanan Minimal, dan Peraturan Menteri Dalam Negeri Nomor 79 Tahun 2007 tentang Pedoman Penyusunan Rencana Pencapaian Standar Pelayanan Minimal.

Kemendagri, demi mempercepat penerapan SPM, melakukan beberapa upaya antara lain (1) Penerbitan Surat Edaran Nomor 100/1023/SJ/ Tanggal 26 Maret 2013 Tentang Percepatan Pelaksanaan Penerapan dan Pencapaian Standar Pelayanan Minimal yang disampaikan kepada Gubernur dan Bupti/Walikota di Seluruh Indonesia yang berisikan. (2) Penyusunan Pedoman Percepatan Penerapan SPM di Daerah. Berupa Panduan berisikan gambaran umum SPM mulai dari kerangka regulasi, pengertian dan status keberadaan SPM. Disamping itu pedoman berisikan panduan teknis penerapan SPM antara lain cara-cara dan mekanisme penyusunan rencana dan pencapaian serta tahapan penyusunan rencana capaian SPM di daerah. (3) Penyusunan Road Map Penerapan SPM Tahun 20132019. Road Map Penerapan SPM adalah merupakan suatu peta jalan bagi seluruh stakeholder atau institusi yang terkait langsung maupun tidak langsung untuk menerapkan SPM secara benar dan efektif serta berkesinambungan di daerah.

Sejak terbitnya PP Nomor 65/2005 telah terdapat 15 bidang pelayanan dasar yang telah ditetapkan SPM, yaitu:

Tabel 1. Data SPM Yang Telah Ditetapkan Sampai Dengan Tahun 2012

\begin{tabular}{|c|c|}
\hline Bidang SPM & Dasar Hukum \\
\hline Perumahan Rakyat & $\begin{array}{l}\text { Peraturan Menteri Negara Perumahan Rakyat RI No. 22/PERMEN /M/2008 } \\
\text { Tentang Standar Pelayanan Minimal Bidang Perumahan Rakyat Daerah Provinsi } \\
\text { dan Daerah Kabupaten/Kota }\end{array}$ \\
\hline $\begin{array}{l}\text { Pemerintah Dalam } \\
\text { Negeri }\end{array}$ & $\begin{array}{l}\text { Peraturan Menteri Dalam Negeri RI No. } 62 \text { Tahun } 2008 \text { tentang Standar } \\
\text { Pelayanan Minimal Bidang Pemerintahan Dalam Negeri di Kabupaten/Kota }\end{array}$ \\
\hline Sosial & $\begin{array}{l}\text { Peraturan Menteri Sosial RI No. 129/huk /2008 tentang standar Pelayanan } \\
\text { Minimal (SPM) Bidang Sosial }\end{array}$ \\
\hline Kesehatan & $\begin{array}{l}\text { Peraturan Menteri Kesehatan RI No.741 Tahun } 2008 \text { Tentang Standar Pelayanan } \\
\text { Minimal Bidang Kesehatan di Kabupaten/Kota }\end{array}$ \\
\hline $\begin{array}{l}\text { Pemberdayaan } \\
\text { Perempuan dan } \\
\text { Perlindungan Anak }\end{array}$ & $\begin{array}{l}\text { Peraturan Menteri Negara Pemberdayaan Perempuan dan Perlindungan Anak RI } \\
\text { No. } 01 \text { tahun } 2010 \text { tentang Standar Pelayanan Minimal Bidang layanan Terpadu } \\
\text { bagi Perempuan dan Anak Korban Kekerasan }\end{array}$ \\
\hline Lingkungan Hidup & $\begin{array}{l}\text { Peraturan Menteri Negara Lingkungan Hidup RI No. } 19 \text { Tahun } 2008 \text { Tentang } \\
\text { Standar Pelayanan Minimal Bidang Lingkungan Hidup Daerah Provinsi dan } \\
\text { Daerah Kabupaten/Kota }\end{array}$ \\
\hline $\begin{array}{l}\text { Keluarga Berencana dan } \\
\text { Sejahtera }\end{array}$ & $\begin{array}{l}\text { Peraturan Kepala badan Koordinasi Keluarga Berencana Nasional No. 55/hk- } \\
\text { 010/b5/2010 tentang Standar Pelayanan Minimal Bidang Keluarga Berencana } \\
\text { dan Keluarga Sejahtera di Kabupaten/Kota }\end{array}$ \\
\hline Ketenaga Kerjaan & $\begin{array}{l}\text { Peraturan Menteri Tenaga Kerja RI No.PER. 15/MEN/X/2010 Tentang Standar } \\
\text { Pelayanan Minimal (SPM) Bidang Ketenagakerjaan Peraturan Menteri Tenaga } \\
\text { Kerja dan Transmigrasi RI No.PER.04/MEN/IV/2011 Tentang Perubahan Atas } \\
\text { Lampiran Peraturan Menteri Tenaga Kerja }\end{array}$ \\
\hline Pendidikan & $\begin{array}{l}\text { Peraturan Menteri Pendidikan Nasional RI No. 15/2010 Tentang Standar } \\
\text { Pelayanan Minimal Bidang Pendidikan Dasar di Kabupaten/Kota }\end{array}$ \\
\hline Pekerjaan Umum & $\begin{array}{l}\text { Peraturan Menteri Pekerjaan Umum RI No.14/PRT/M/2010 Tentang SPM } \\
\text { Bidang Pekerjaan Umum dan Penataan Ruang }\end{array}$ \\
\hline Ketahanan Pangan & $\begin{array}{l}\text { Peraturan Menteri Pertanian RI No.65/Permentan/OT.140/12/2010 Tentang } \\
\text { Standar Pelayanan Minimal Bidang Ketahanan Pangan Provinsi dan } \\
\text { Kabupaten/Kota }\end{array}$ \\
\hline Kesenian & $\begin{array}{l}\text { Peraturan Menteri Kebudayaan \& Pariwisata RI No.PM.106/HK.501/MKP/2010 } \\
\text { Tentang Standar Pelayanan Minimal Bidang Kesenian }\end{array}$ \\
\hline $\begin{array}{l}\text { Komunikasi dan } \\
\text { Informasi }\end{array}$ & $\begin{array}{l}\text { Peraturan Menteri Kemkominfo RI No.22/PER/M.KOMINFO/12/2010 tentang } \\
\text { Standar Pelayanan Minimal Bidang Komunikasi dan Informatika di } \\
\text { Kabupaten/Kota }\end{array}$ \\
\hline
\end{tabular}

Sumber: Kementerian Dalam Negeri (2012) 
SPM sebanyak 15 jenis tersebut ditambah lagi penerbitan SPM di bidang perhubungan melalui Peraturan Menteri Perhubungan Nomor 81 Tahun 2011 tentang Standar Pelayanan Minimal Bidang Perhubungan Daerah Provinsi dan Daerah Kabupaten/Kota dan Peraturan Menteri Perhubungan Republik Indonesia Nomor PM. 2 Tahun 2013 Tentang Petunjuk Teknis Penerapan Dan Pencapaian Standar Pelayanan Minimal Bidang Perhubungan Daerah Provinsi Dan Daerah Kabupaten/Kota. Kemudian juga terdapat SPM di bidang penanaman modal melalui Peraturan Kepala BKPM Nomor 14 Tahun 2011 Pelayanan Minimal Bidang Penanaman Modal Provinsi dan Kabupaten/Kota dan Peraturan Kepala Kepala Badan Koordinasi Penanaman Modal Republik Indonesia Nomor 10 Tahun 2012 Tentang Petunjuk Teknis Standar Pelayanan Minimal Bidang Penanaman Modal Provinsi dan Kabupaten/Kota, sehingga total terdapat 15 bidang yang telah ada pengaturan tentang SPM.

Namun demikian, perubahan UU 32/2004 ke UU Pemda menyebabkan terjadinya reduksi jumlah Urusan Pemerintahan Wajib yang berkaitan dengan Pelayanan Dasar berdasarkan UU Pemda, dari 15 bidang menjadi 6 bidang saja, yaitu:

1) Pendidikan;

2) Kesehatan;

3) Pekerjaan Umum dan Penataan Ruang;

4) Perumahan Rakyat dan Kawasan Permukiman;

5) Ketentraman, Ketertiban Umum, dan Perlindungan Masyarakat; dan

6) Sosial

Pada akhirnya, memperhatikan berbagai narasi normative tersebut, maka sudah kewajiban bagi Provinsi Kalimantan Timur berikut kabupaten/kota yang berada di lingkungannya untuk menerapkan berbagai macam ketentuan tersebut. Hal ini mengandung arti bahwa Pemerintah Provinsi Kalimantan Timur dan 10 Kabupaten/Kota yang ada di wilayahnya harus sudah melakukan penerapan SPM berikut perencanaan, target, penganggaran, dan evaluasinya. Hal inilah yang menarik untuk dijadikan isu penelitian, terkait dengan penerapan dan pencapaian SPM di wilayah Provinsi Kalimantan Timur.

\section{Landasan Teori}

UU Nomor 32 Tahun 2004 merupakan tonggak baru penyelenggaraan pemerintahan daerah di Indonesia pasca orde baru yang banyak dikenal sebagai orde sentralistik, salah satu penopang tonggak tersebut adalah Standar Pelayanan Minimal. Pasal 11 ayat (3) UU No. 32 Tahun 2004 menyebutkan bahwa urusan wajib harus dilaksanakan oleh daerah berdasarkan Standar Pelayanan Minimal (SPM) dan dilaksanakan secara bertahap. Guna menindak lanjuti perwujudan SPM, maka pemerintah mengeluarkan regulasi sebagai pedoman penerapan SPM melalui PP No. 65 Tahun 2005. Dijelaskan dalam salah satu ketentuan umumnya bahwa urusan wajib sebagai dasar penerapan SPM merupakan urusan pemerintahan yang berkaitan dengan hak dan pelayanan dasar warga negara yang penyelenggaraannya diwajibkan oleh peraturan perundang-undangan kepada daerah untuk perlindungan hak konstitusional, kepentingan nasional, kesejahteraan masyarakat, serta ketentraman dan ketertiban umum dalam rangka menjaga keutuhan Negara Kesatuan Republik Indonesia serta pemenuhan komitmen nasional yang berhubungan dengan perjanjian dan konvensi international.

Selanjutnya, mengenai definisi Standar Pelayanan Minimal yang selanjutnya disingkat SPM dijelaskan di dalam Pasal 1 angka 6 yakni: ketentuan tentang jenis dan mutu pelayanan dasar yang merupakan urusan wajib daerah yang berhak diperoleh setiap warga secara minimal. Lebih lanjut disebutkan bahwa SPM bersifat sederhana, konkrit, mudah diukur, terbuka, terjangkau, dan dapat dipertanggung jawabkan serta mempunyai batas waktu pencapaian. Rencana pencapaian SPM disusun oleh pemerintah daerah dengan memuat target tahunan pencapaian SPM dengan mengacu pada batas waktu pencapaian SPM sesuai dengan peraturan menteri. SPM yang telah tersusun akan menjadi pedoman bagi kedua belah pihak, pemerintah daerah maupun masyarakat. Bagi pemerintah daerah SPM dijadikan pedoman dalam melakukan pelayanan publik, sedangkan bagi masyarakat SPM merupakan pedoman untuk memantau dan mengukur kinerja pemerintah daerah. Penerapan Standar Pelayanan Minimal (SPM) memiliki nilai yang sangat strategis, baik bagi pemerintah daerah maupun bagi masyarakat sebagai konsumen. Keberadaan SPM dapat dijadikan acuan kualitas dan kuantitas suatu pelayanan publik. Penerapan SPM yang dilakukan oleh setiap kepala daerah dan menjadi tolak ukur kinerja pemerintah daerah terhadap peningkatan mutu dan jenis pelayanan kepada masyarakat. 
Sedangkan bagi masyarakat, hak mereka untuk terlayani melalui Standar Pelayanan Minimal (SPM) yang wajib dipenuhi oleh pemerintah daerah.

Keberadaan SPM otomatis menuntut Pemerintah untuk selalu memberikan pelayanan prima kepada masyarakat. Standar baku yang menjadi pedoman pemberian pelayanan publik dalam SPM, seakan berbentuk "kontrak" antara pemerintah sebagai pelayan dan publik sebagai yang dilayani. Pengingkaran "kontrak" berarti pengingkaran komitmen pemerintah terhadap kepuasan publik, dengan kata lain, kinerja pemerintah layak dipertanyakan.

Dalam scope lebih luas di level pemerintahan daerah, untuk lebih membumikan pelaksanaan SPM, rencana pencapaian SPM dituangkan dalam Rencana Pembangunan Jangka Menengah Daerah (RPJMD) dan Rencana Strategis Satuan Kerja Perangkat Daerah (Renstra SKPD). Lebih konkrit lagi agar terimplementasikan di satuan terknis pelaksnaannya, Pasal 9 ayat (5) PP No. 5 Tahun 2005 menkrokretkan bahwa Target tahunan pencapaian SPM sebagaimana dimaksud pada ayat (3) dituangkan ke dalam Rencana Kerja Pemerintah Daerah (RKPD), Rencana Kerja Satuan Kerja Perangkat Daerah (Renja SKPD), Kebijakan Umum Anggaran (KUA), Rencana Kerja dan Anggaran Satuan Kerja Perangkat Daerah (RKA-SKPD) sesuai klasifikasi belanja daerah dengan mempertimbangkan kemampuan keuangan daerah.

Dalam konsepnya, SPM sudah dipertimbangkan dari segala aspek dalam hal memaksimalkan rencana pencapaian/target SPM, salah satunya adalah mensosialisasikannya kepada masyarakat. Pasal 11 PP No. 65 tahun 2005 menyebutkan bahwa rencana pencapaian target tahunan SPM sebagaimana dimaksud dalam Pasal 9 ayat (3), ayat (4) dan ayat (5) serta realisasinya diinformasikan kepada masyarakat sesuai pertaturan perundang - undangan. Jika konsep ini terealisasi dengan baik di lapangan, maka diharapkan akan dapat mereduksi kegagalan-kegagalan pencapaian SPM. Hal ini dIkarenakan jika masyarakat diposisikan sebagai subyek yang terlayani dari adanya SPM, maka secara otomatis masyarakat akan aware pada SPM dengan keterlibatannya dalam memberikan input rencana dan feedback dari pelaksnaannya. Kondisi berbeda tentu akan terjadi jika masyarakat hanya dijadikan obyek yang diposisikan pasif dalam rencana dan realisasi SPM. Upaya pemaksimalan lainnya dalam upaya pencapaian rencana SPM sebagaimana tersebut dalam Pasal 12 PP No. 65 Tahun 2005 adalah Pemerintahan Daerah mengakomodasikan pengelolaan data dan informasi penerapan SPM ke dalam sistem informasi daerah yang dilaksnakan sesuai dengan peraturan perundang-undangan. Pertanyaan selanjutnya adalah, sudahkah daerah melakukannya, jika tidak adakah sanksinya?

Dalam upaya Pencapaian SPM, pemerintah 'sepertinya' sudah menyadari segala kendala jika harus dilakukan sendiri. Segala keterbatasan (baik SDM dan dana) yang selalu menjadi alasan klasik dalam kebijakan apapun, dicoba dicarikan solusinya sebagaiman tersebut dalam pasal 13 ayat (3) PP No. 65 tahun 2005 bahwa: dalam upaya pencapaian SPM Pemerintah Daerah dapat bekerjasama dengan pihak swasta. Dengan demikian, idealnya tidak ada lagi alasan bagi daerah untuk 'gagal target' dikarenakan keterbatasan.

Setelah tahap rencana dan pencapaian sudah terkonsep dengan baik, yang tidak kalah krusialnya dari penerapan sebuah kebijakan adalah proses pembinaan dan evaluasi. Pasal 14 ayat (1): PP No. 65 tahun 2005 menyebutkan bahwa Menteri/Pimpinan Lembaga Pemerintah Non-Departemen melakukan pembinaan kepada Pemerintah Daerah dalam penerapan SPM. Lebih lanjut dalam Pasal 14 ayat (2) dijelaskan bahwa Pembinaan sebagaimana dimaksud dalam ayat (1) dapat berupa fasilitasi, pemberian orientasi umum, petunjuk teknis, bimbingan teknis, pendidikan dan pelatihan atau bantuan teknis lainnya yang mencakup:

Perhitungan sumber daya dan dana yang dibutuhkan untuk mencapai SPM, termasuk kesenjangan pembiayaannya;

a) Penyusunan rencana pencapaian SPM dan penetapan target tahunan pencapaian SPM

b) Penilaian prestasi kerja pencapaian SPM; dan

c) Pelaporan prestasi kerja pencapaian SPM.

Adapun gradasi pembinaan SPM terdapat pengaturannya di Pasal 14 ayat (3) PP No. 65 Tahun 2005 yang berbunyi: Pembinaan penerapan SPM terhadap Pemerintah daerah Provinsi dilakukan oleh Pemerintah, dan pembinaan penerapan SPM terhadap Pemerintahan Daerah Kabupaten/Kota dilakukan oleh Gubernur sebagai Wakil Pemerintah di daerah. Daerah dalam rangka menjamin akses dan mutu pelayanan kepada masyarakat. 
Terkait proses pembinaan, Pasal 16 ayat (1) PP no. 65 tahun 2005 menyatakan bahwa Pemerintah wajib mendukung pengembangan kapasitas Pemerintahan daerah yang belum mencapai SPM. Jika SPM belum mampu untuk dicapai oleh suatu daerah, maka Pemerintah dapat melimpahkan tanggung jawab pengembangan kapasitas Pemerintahan daerah Kabupaten/Kota yang belum mampu mencapai SPM kepada Gubernur sebagai wakil Pemerintahan di daerah (Pasal 16 ayat (2)). Namun demikian, tidak serta merta pemerintah daerah dapat menyatakan ketidakmampuannya dalam mencapai SPM sehingga tanggung jawab dapat dialih tangankan, ketidakmampuan Pemerintah Daerah dalam mencapai SPM sebagaimana dimaksud pada ayat (1) ditetapkan pemerintah berdasarkan pelaporan dan hasil evaluasi penyelenggaraan Pemerintahan Daerah dengan peraturan perundang-undangan (Pasal 16 ayat (3)).

Point terakhir yang tidak kalah pentingnya dari pelaksanaan SPM berdasar PP Nomor 65 Tahun 2005 adalah mengenai penghargaan kepada Pemerintahan Daerah yang berhasil mencapai SPM dengan baik dalam batas waktu yang ditetapkan dalam Peraturan Menteri sebagaimana dimaksud pada Pasal 9 ayat (3) berdasarkan hasil evaluasi yang dilakuakn oleh pemerintah (Pasal 18). Dalam pasal selanjutnya, (Pasal 19 ayat (1)) disebutkan bahwa Pemerintah dapat memberikan sanksi kepada Pemerintah Daerah yang tidak berhasil mencapai SPM dengan baik dalam batas waktu yang ditetapkan dalam Peraturan Menteri sebagaiamana dimaksud dalam Pasal 9 ayat (3) berdasarkan hasil monitoring dan evaluasi sebagaimana dimaksud dalam Pasal 15 dengan mempertimbangkan kondisi khusus daerah yang bersangkutan.

Setelah pedoman penyusunan dan penerapan SPM dibuat melalui PP No. 65 Tahun 2005, maka Kemendagri selaku 'pengayom' Pemerintahan Daerah, menindak lanjutinya dengan membuat regulasi berupa Peraturan Mendagri mengenai Pedoman Penyusunan Rencana Pencapaian SPM. Peraturan bernomor 79 Tahun 2007 tersebut memuat beberapa point lanjutan secara spesifik dari PP No. 65 tahun 2005 seperti ketentuan di Pasal 11 yang berisikan tentang Nota Kesepakatan tentang KUA dan PPA yang disepakati bersama antara Kepala Daerah dengan Pimpinan DPRD wajib memuat target pencapaian dan penerapan SPM. Secara spesifik juga diatur dalam permendagri ini mengenai waktu pelaksanaan evaluasi. Di dalam Pasal 21 ayat (2) disebutkan bahwa Monitoring dan evaluasi sebagaiamana dimaksud pada ayat (1) dilaksanakan paling sedikit setahun oleh Menteri/Pimpinan Lembaga Pemerintah Non-Departemen terkait. Dalam pasal selanjutnya (Pasal 22) dikatakan bahwa hasil monitoring dan evaluasi penerapan dan pencapaian SPM sebagaimana dimaksud dalam Pasal 20 dan Pasal 21 dipergunakan Pemerintah sebagai: Bahan masukan bagi pengembangan kapasitas pemerintahan daerah dalam pencapaian SPM; dan Bahan pertimbangan dalam pembinaan dan pengawasan penerapan SPM, termasuk pemberian penghargaan bagi Pemerintah Daerah yang berprestasi sangat baik.

Menjadi pertanyaan menggelitik saat ini adalah: setelah berjalan kurang lebih 11 tahun, bagaimanakah kondisi SPM saat ini? Di dalam prakteknya, ternyata pelaksanaan SPM tidak seindah sebagaimana konsepnya. Berikut beberapa ringkasan terkait berbagai kendala yang menjadi permasalahan dalam upaya pencapaian penerapan SPM. Beberapa kendala ini dirangkum dari buku, karya Prof. Agus Dwiyanto (Administrasi Publik), antara lain:

1) Tidak jelasnya hubungan antara penyerahan urusan dengan sumber pembiayaannya mendorong pemerintah untuk mengalihkan banyak urusan kepada daerah. Salah satu penyebabnya adalah rendahnya kemampuan daerah membiayai penyelenggaraan pelayanan dasar sebagaimana diatur dalam SPM

2) Selama ini beberapa kajian terdahulu menunjukkan adanya kendala dalam implementasi SPM, diantaranya rendahnya komitmen dan keperdulian aktor - aktor daerah terhadap pelaksnaan SPM, terbatasnya sumber daya yang tersedia untuk implementasi SPM sebagai akibat mismanajemen dalam penyelenggaraan pemerintahan daerah, rendahnya efektivitas monitoring, serta evaluasi dan Binwas yang dilakukan oleh Kementeriaan Lembaga.

3) Pada tataran regulasi, masalah juga muncul ketika beberapa SPM yang dirumuskan tidak mampu membedakan standar untuk propinsi dan Kabupaten. Indikator SPM propivinsi dalam penyelenggaraan pelayanan tertentu mestinya diukur dari besaran usaha dan hasil yang dilakukan oleh Provinsi yang bersangkutan, bukan oleh Kinerja Kabupaten/Kota yang ada di wilayahnya. 
4) Ketika indikator SPM tidak jelas dan tidak terkait dengan kegiatan yang dilakukan oleh susunan pemerintahan tertentu, tentu indikator tersebut tidak dapat digunakan untuk melakukan monitoring dan evaluasi. Indikator itu juga tidak dapat menjadi inspirasi bagi aktor terkait untuk mencapaianya.

5) Pencapaian indikator SPM dalam bidang tertentu dapat dipergunakan sebagai bagian dari kontrak kinerja antara provinsi dan kabupaten antara provinsi dan kabupaten/kota dengan para pejabat publik yang bertanggung jawab mengelola berbagai pelayanan dasar.

6) Rendahnya efektivitas implementasi SPM di daerah banyak ditelusuri salah satunya dari kecilnya upaya pemerintah untuk benar-benar menempatkan SPM sebagai arus utama dalam penyelenggaraan pemerintahan di daerah. Namun persoalannya, penerbitan regulasi dan surat edaran tidak cukup untuk menjadikan daerah perduli pada pelaksnaan SPM. Para aktor di daerah seperti Kepala daerah, DPRD dan pimpinan SKPD belum memiliki insentif yang memadai untuk benar-benar menjadikan SPM sebagai prioritas dalam penyelenggaraan pemerintahan daerah. Mereka menganggap bahwa berhasil tidaknya mereka mencapai indikator SPM tidak banyak berpengaruh terhadap nasib dan kepentingannya.

7) Tranformasi peran kementerian dan lembaga dalam pelaksnaan SPM belum berhasil dilakukan. Salah satu indikasinya adalah kecenderungan kementerian dan lembaga merasa tugasnya sudah selesai ketika mereka sudah berhasil menerbitkan SPM. Pelaksnaan SPM seolah-olah menjadi urusan sepenuhnya pemerintah daerah. Hal ini terlihat dari ketidakseriusan kementerian dan lembaga menjalankan fungsi Binwas, keengganan mereka untuk mengaitkan dana DAK dan sumber-sumber lainnya untuk memberdayakan daerah dalam pelaksnaan SPM, dan tidak adanya evaluasi yang serius yang dilakukan kementerian dan lembaga terhadap pelaksnaan SPM oleh daerah.

Terakhir dalam ulusannya mengenai SPM, disebutkan oleh Agus Dwiyanto, bahwa berbagai fenomena di atas menunjukkan bahwa keberhasilan pelaksnaan SPM belum menjadi agenda yang penting bagi kementerian dan lembaga. Kinerja pelaksanaan SPM dinilai tidak ada kaitannya dengan kinerja kementerian dan lembaga. Oleh karenanya tidak mengherankan kalau insentif dan disisentif terhadap daerah atas keberhasilannya dalam pelaksanaan SPM boleh dikatakan tidak ada sama sekali. Bahkan walaupun pelaksanaan SPM menjadi salah satu indikator dalam penilaian kinerja penyelenggaraan pemerintah daerah (LPPD), tetapi bobotnya amat kecil. Ini semua membuktikan bahwa pengarus utamaan SPM dalam penyelenggaraan pemerintahan di kementerian dan lembaga belum secara sungguh-sungguh dilaksanakan.

Melengkapi pembahasan SPM dari sisi teori dan praktek, perlu untuk mendapat perhatian saat ini adalah berubahnya undang-undang tentang pemerintahan daerah yang menjadi payung pelaksnaan SPM. UU No. 32 Tahun 2004 telah diganti saat ini dengan UU No. 23 tahun 2014. Dalam penjelasan umumnya disebutkan bahwa pada dasarnya perubahan Undang-Undang Nomor 32 Tahun 2004 tentang Pemerintahan Daerah ditujukan untuk mendorong lebih terciptanya daya guna dan hasil guna penyelenggaraan Pemerintahan Daerah dalam menyejahterakan masyarakat, baik melalui peningkatan pelayanan publik maupun melalui peningkatan daya saing Daerah. Perubahan ini bertujuan untuk memacu sinergi dalam berbagai aspek dalam penyelenggaraan Pemerintahan Daerah dengan Pemerintah Pusat.

Terkait urusan wajib yang berkaitan dengan pelayanan dasar sebagai bagian dari penerapan SPM, mengalami 'reduksi' dari sisi jumlahnya. Saat ini hanya terdapat 6 (enam) pelayanan dasar sebagaimana tersebut di dalam Pasal 12, yakni:

a) Pendidikan

b) Kesehatan

c) Pekerjaan Umum dan Penataan ruang

d) Perumahan rakyat dan kawasan pemukiman

e) Ketentraman, ketertiban umum dan perlindungan masyarakat, dan

f) sosial

Dari perubahan tersebut perlu menunggu waktu untuk melihat apakah indikator dari urusan wajib yang sama masih relevan dengan menggunakan indikator yang sama? Ataukah untuk menjawab kualitas penyelenggara pemerintahan, pemerintah perlu dengan segera membuat semua indikator 
pelayanan dasar tersebut secara baru, hal ini berangkat dari kondisi saat ini dimana berbagai perubahan kebijakan di lingkungan penyelenggaraan pemerintahan telah terjadi secara masif di berbagai sektor plus kondisi masyarakat yang sudah kritis terkait hak-hak administrasi kewarganegaraannya.

\section{METODE PENELITIAN}

\section{Ruang Lingkup Penelitian}

Penelitian ini berlokasi di Provinsi Kalimantan Timur, namun mengingat masih banyak dan luasnya kabupaten/kota di provinsi yang baru dimekarkan ini, maka lokasi penelitian perlu dibatasi. Alasan lain pembatasan lokasi penelitian adalah, karena adanya keterbatasan waktu, tenaga dan biaya. Dengan demikian, diperlukan pengambilan sampel kabupaten/kota, yang dianggap dapat mewakili atau mencerminkan Provinsi Kalimantan Timur secara keseluruhan. Adapun pengambilan sampel wilayah dalam kajian ini menggunakan metode purposive sampling, dimana lokus yang dipilih dalam penelitian ini terdiri dari 4 (empat) Kabupaten/Kota, yakni Kota Samarinda, Kota Balikpapan, Kabupaten Kutai Kartanegara dan Kabupaten Berau.

Sedangkan fokus penelitian ini adalah penerapan dan pencapaian Standar Pelayanan Minimal (SPM) di Provinsi Kalimantan Timur, seperti diatur oleh UU Nomor 32 Tahun 2004 dan berbagai macam peraturan perundang-undangan di bawahnya tanpa mengesampingkan pengaturan SPM yang terdapat pada UU Nomor 23 Tahun 2014. Mengingat fokus penelitian ini hampir identik dengan pelaksanaan evaluasi, maka pendekatan utama yang akan digunakan adalah pendekatan survey, observasi, wawancara terstruktur dan penyebaran angket kepada responden. Pemilihan responden penelitian sementara itu dilakukan dengan cara purposive sampling.

\section{Tahapan Penelitian}

Penelitian direncanakan dilakukan dengan beberapa tahapan, sesuai dengan panduan penelitian yang berlaku, yaitu:

1) Persiapan Penelitian

Persiapan penelitian terdiri dari kegiatan penyusunan kerangka acuan (terms of reference), Proposal dan instrumen penelitian (questionnaire); penetapan lokasi dan sampel penelitian; penyempurnaan desain penelitian (research design); serta persiapan administratif lainnya (pembentukan tim, rapatrapat pembahasan, rencana survei lapangan, persuratan, dll).

2) Pengumpulan Data

Pengumpulan data mencakup kegiatan studi referensi dan survey lapangan ke lokasi penelitian. Survey lapangan disertai dengan penyebaran kuesioner dan wawancara dengan beberapa stakeholder pendidikan.

3) Pengolahan dan Analisis Data

Data yang telah terkumpul diolah untuk kemudian dianalisis, dengan menggunakan alat analisis tertentu. Jika diperlukan, data aktual yang terolah perlu dilakukan klarifikasi ulang ke lokus penelitian untuk memperoleh akurasi informasi, sehingga analisis dapat dijamin lebih akurat.

4) Penulisan Laporan Awal

Penulisan laporan awal merupakan hasil analisis dalam bentuk draft laporan awal (termasuk executive summary) diseminarkan untuk memperoleh pandangan dan pengukuhan para ahli yang tergabung dalam Tim Pengendali Mutu (TPM).

5) Penyusunan Laporan Akhir

Laporan Akhir disusun setelah dilakukan perbaikan pada Laporan Awal. Perbaikan Laporan Awal untuk menuju Laporan Akhir dilakukan berdasarkan masukan-masukan dari para peserta seminar laporan penelitian.

\section{Responden dan Informan Kunci Penelitian}

Kabupaten/kota yang dijadikan sebagai sampel wilayah Provinsi Kalimantan Timur dalam penelitian ini, adalah: Kota Samarinda dan Kota Balikpapan mewakili Kota, dan Kabupaten Berau serta Kabupaten Kutai Kartanegara mewakili Kabupaten. Masing-masing kabupaten/kota yang menjadi sampel wilayah terpilih, akan terdiri atas beberapa responden dan beberapa informan kunci. Responden dan Informan Kunci ditetapkan secara purposif. Penggalian data dari responden penelitian dilakukan 
dengan menggunakan instrumen kuesioner. Sedangkan penggalian data dari informan kunci dilakukan dengan menggunakan instrumen pedoman wawancara.

Responden penelitian di masing-masing wilayah, berasal dari pelaksana SPM di SKPD yang melaksanakan SPM. Dengan demikian, setiap wilayah penelitian akan terdiri atas 6 - 15 responden yang mewakili 6-15 SKPD pelaksana SPM. Informan kunci di sisi lain, terdiri atas beberapa pejabat penanggungjawab SPM, di antaranya adalah Kabag Organisasi Tata Laksana, dan Kabid Data dan Pelaporan Bappeda.

\section{Desain Penelitian}

Adapun desain dari penelitian ini, secara ringkas dapat dilihat pada Gambar 1 di bawah ini:

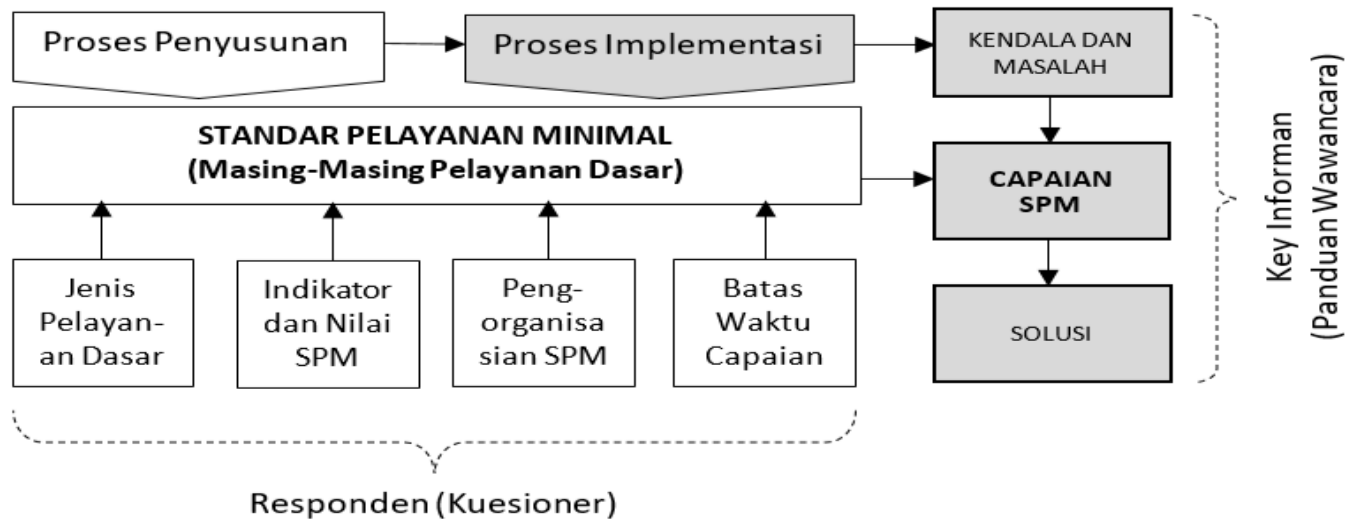

Gambar 1. Kerangka Pikir Penelitian

\section{Instrumen Penelitian}

Instrumen yang dikembangkan dalam penelitian ini adalah instrumen untuk memperoleh data primer dan data sekunder. Instrumen yang dikembangkan untuk memperoleh data primer adalah kuesioner dan pedoman wawancara. Kuesioner dan pedoman wawancara dikembangkan untuk mencapatkan data peneitian yang terkait dengan indikator kunci penelitian yaitu proses penyusunan dan implementasi serta kendala Standar Pelayanan Minimal (SPM) masing-masing pelayanan dasar. Sementara itu instrumen yang dikembangkan untuk memperoleh data sekunder adalah dokumentasi hasil capaian SPM di setiap kabupaten/kota sampel. Pada dasarnya instrumen disusun untuk menjawab pertanyaan penelitian, sehingga peneliti dapat merekomendasi berbagai solusi kepada pemerintah untuk meningkatkan mutu dan kualitas implementasi SPM di Kabupaten/Kota Provinsi Kalimantan Timur.

Kuesioner akan yang digunakan dalam penelitian ini, kongkritnya berbentuk tertutup, langsung dan tidak langsung, dan dengan jawaban berupa skala bertingkat (rating scale). Kuesioner tertutup adalah kuesioner yang jawabannya sudah disediakan dan responden tinggal memilih jawaban dari variasi jawaban yang tersedia. Indikator-indikator Standar Pelayanan Minimal seperti terlihat dalam Gambar 3.1 dijabarkan ke dalam dua indikator utama, yaitu proses penyusunan SPM dan proses implementasi SPM, yang setiap setiap indikator terdiri atas beberapa sub indikator yaitu: a) Jenis Pelayanan Dasar, b) Indikator dan Nilai SPM, c) Pengorganisasian SPM, dan d) Batas Waktu Pencapaian SPM.

Panduan wawancara di sisi lain, juga mengacu kepada dua indikator utama dan empat sub indikator dari indikator utama. Meskipun indikator utama dan sub indikator adalah sama, namun redaksisional pedoman wawancara berbeda dengan kuesioner. Jika kuesioner diarahkan untuk jawaban tertutup, maka pedoman wawancara diarahkan untuk jawaban terbuka, sehingga data penelitian dapat digali sedalam mungkin. Dengan demikian sasaran kuesioner adalah responden,sedangkan pedoman wawancara aalah informan kunci.

\section{Alat Analisis Data}

Data dianalisis dengan menggunakan alat analisis statistik deskriptif. Statistik Deskriptif digunakan untuk mengetahui kecenderungan data secara deskriptif, sedangkan statistik inferensial digunakan untuk menentukan perbedaan yang nyata secara statistik pada setiap kelompok indikator 
utama dan sub indikator Standar Pelayanan Minimal. Statistik Deskriptif yang digunakan adalah tendensi sentral yang disajikan dalam bentuk tabel silang berupa tabel frekuensi dan prosentasi. Statistik Deskriptif digunakan untuk menjawab pertanyaan penelitian 1, 2, 3 dan 4.

\section{HASIL DAN PEMBAHASAN}

\section{Penerapan dan Pencapaian Standar Pelayanan Minimal}

\section{Kota Balikpapan}

\section{a. Pendidikan}

Pemerintah daerah wajib memiliki SPM dalam penyelenggaraan pelayanan publik termasuk diantaranya Pemerintah Kota Balikpapan. Dalam UU Pemda terbaru, terdapat 6 (enam) bidang pelayanan dasar yang wajib memiliki SPM yaitu bidang pendidikan, bidang kesehatan, bidang Ketentraman, Ketertiban Umum dan Perlindungan masyarakat, bidang Sosial, bidang pekerjaan umum dan penataan ruang dan bidang perumahan rakyat.

Pada dasarnya, rencana pencapaian SPM sebagian besar telah tergambar dalam program dan kegiatan SKPD terkait. Dalam bidang pendidikan misalnya, Dinas Pendidikan Kota Balikpapan sebagai pengampu SPM bidang pendidikan dasar telah memasukkan rencana pencapaian SPM bidang pendidikan di Kota Balikpapan dalam Renja SKPD Dinas Pendidikan yang dilaksanakan dalam bentuk program dan kegiatan.

Standar Pelayanan Minimal (SPM) Bidang Pendidikan Dasar diatur di dalam Permendikbud Nomor 23 Tahun 2013 Tentang Perubahan Atas Peraturan Menteri Pendidikan Nasional Nomor 15 Tahun 2010 Tentang Standar Pelayanan Minimal Pendidikan Dasar di Kabupaten/Kota. Dalam Permendikbud tersebut disebutkan bahwa target pencapaian pelayanan dasar bidang pendidikan harus tercapai pada akhir tahun 2014. Pemerintah Kota Balikpapan sendiri memiliki Perda Nomor 4 Tahun 2009 tentang SPM Pendidikan di Kota Balikpapan.

Adapun capaian SPM Bidang Pendidikan dalam kurun waktu 2011-2015 adalah:

1) Pelayanan dasar yang dilaksanakan oleh Kota Balikpapan rata-rata selama 2011-2015 adalah 79\% (14 indikator)

2) Pelayanan dasar yang dilaksanakan satuan pendidikan Kota Balikpapan rata-rata selama 20112015 adalah $88 \%$ (13 indikator)

Persentase rata-rata diperoleh dari nilai average capaian per indikator per jenjang pelayanan (SD, SMP, SMA).

\section{b. Kesehatan}

Jenis pelayanan dan indikator Standar Pelayanan Minimum Dinas Kesehatan mengacu pada Peraturan Menteri Kesehatan RI Nomor 741/MENKES/Tahun 2008 Tentang Standar Pelayanan Minimal Bidang Kesehatan di Kabupaten/Kota; dan Keputusan Menteri Kesehatan RI Nomor 828/MENKES/SK/IX/2008 Tentang Petunjuk Teknis Standar Pelayanan Minimal Bidang Kesehatan Di Kabupaten/Kota. Secara keseluruhan berikut adalah indikator SPM bidang kesehatan Kota Balikpapan, termasuk program dan kegiatan yang diterapkan dalam memenuhi indikator SPM tersebut.

Menurut Kepala Sub Bagian Perencanaan Program dan Sekretaris Dinas Kesehatan Balikpapan dr. Elizabeth Rassi dan drg. Suheriyono, M.Kes sebenarnya tidak banyak kendala yang dihadapi dalam pelaksanaan SPM bidang kesehatan di Kota Balikpapan karena penerapan SPM pada dasarnya sudah diimplementasikan sejak lama. Namun demikian, sama halnya dengan kendala pada SKPD teknis yang lain, terdapat sedikit kerancuan dalam menterjemahkan definisi operasional yang tertuang dalam peraturan perundangan mengenai SPM terkait dengan pelayanan kesehatan dasar kepada penduduk miskin.

\section{c. PU dan Pemukiman serta Tata Ruang}

Penerapan SPM bidang pekerjaan umum dan penataan ruang di Kota Balikpapan didasarkan pada ketentuan Peraturan Menteri Negara PU Nomor 01 Tahun 2014 tentang Standar Pelayanan Minimal Bidang Pekerjaan Umum dan Penataan Ruang Kabupaten/Kota. Pada Pasal 7 ayat (1) Permen PU tersebut dicantumkan bahwa terdapat 5 jenis pelayanan dasar yaitu sumber daya air, jalan, cipta karya, jasa konstruksi, dan penataan ruang.

Capaian SPM Pemukiman dan Tata Ruang Kota Balikpapan pada Tahun 2015 adalah: 
1) Sumberdaya air, rata-rata mencapai $35 \%$ (2 indikator)

2) Jalan, rata-rata mencapai $65 \%$ (2 indikator)

3) Cipta Karya, rata-rata mencapai $15 \%$ (8 indikator)

4) Konstruksi, rata-rata mencapai $100 \%$ (2 indikator)

5) Penataan Ruang, rata-rata mencapai $62,5 \%$ (2 indikator)

\section{d. Satuan Polisi Pamong Praja}

Merujuk pada Pasal 12 ayat (1) Undang-Undang Nomor 23 Tahun 2014 tentang Pemerintahan Daerah sebagaimana terakhir kalinya diubah dengan Undang-Undang Nomor 9 Tahun 2015 tentang Perubahan Kedua Atas Undang-Undang Nomor 23 Tahun 2014 tentang Pemerintahan Daerah (selanjutnya akan ditulis UU Pemda), ketentraman, ketertiban umum, dan perlindungan masyarakat terklasifikasi sebagai salah satu urusan pemerintahan wajib yang berkaitan dengan pelayanan dasar.

Namun demikian, ketentuan SPM untuk urusan ketentraman, ketertiban umum, dan perlindungan masyarakat masih berpedoman pada Peraturan Menteri Dalam Negeri RI Nomor 62 Tahun 2008 tentang Standar Pelayanan Minimal Bidang Pemerintahan Dalam Negeri di Kabupaten/Kota sebagaimana diubah dengan Permendagri Nomor 69 Tahun 2012 Tentang Perubahan Atas Peraturan Menteri Dalam Negeri Nomor 62 Tahun 2008 Tentang Standar Pelayanan Minimal Bidang Pemerintahan Dalam Negeri Di Kabupaten/Kota.

Dalam Permendagri tersebut, jenis pelayanan dasar yang ditetapkan adalah Pemeliharaan ketertiban umum, ketentraman masyarakat dan perlindungan masyarakat, dengan indikator:

1) Cakupan penegakan peraturan daerah dan peraturan kepala daerah di kabupaten/kota $(100 \%$, tercapai pada tahun 2015);

2) Cakupan patroli siaga ketertiban umum dan ketentraman masyarakat (3 x patroli dalam sehari, tercapai pada tahun 2014); dan

3) Cakupan rasio petugas perlindungan masyarakat (Linmas) di Kabupaten/Kota (1 orang setiap RT atau sebutan lainnya, tercapai pada tahun 2014).

Adapun dalam hal penerapan SPM untuk urusan ketentraman, ketertiban umum, dan perlindungan masyarakat di Kota Balikpapan sesuai dengan Lampiran I Permendagri Nomor 69 Tahun 2012 Tentang Perubahan Atas Peraturan Menteri Dalam Negeri Nomor 62 Tahun 2008 Tentang Standar Pelayanan Minimal Bidang Pemerintahan Dalam Negeri Di Kabupaten/Kota dibebankan kepada Satuan Polisi Pamong Praja (Satpol PP) Kota Balikpapan yang merupakan salah satu perangkat daerah yang dibentuk sesuai dengan Peraturan Daerah Kota Balikpapan Nomor 2 Tahun 2013 tentang Organisasi dan Tata Kerja Satuan Polisi Pamong Praja Kota Balikpapan dan Peraturan Walikota Balikpapan Nomor 40 Tahun 2013 tentang Uraian Tugas, Fungsi, dan Tata Kerja Satuan Polisi Pamong Praja. Tugas dan fungsi dari Satpol PP ini diantaranya adalah pelaksanaan kebijakan ketentraman, ketertiban umum, dan perlindungan masyarakat di Kota Balikpapan, termasuk di dalamnya pencapaian SPM.

Dalam penerapannya, Satpol PP Kota Balikpapan telah menerapkan sebagian indikator SPM yang ditetapkan dengan program-program antara lain:

1) Pengawasan, pengendalian, dan evaluasi kegiatan satlinmas;

2) Pelatihan linmas dasar dan lanjutan;

3) Penindakan, penyelidikan, monitoring, dan evaluasi terhadap pelanggar Perda;

4) Operasional khusus/razia koordinasi ketentraman dan ketertiban dalam rangka penegakan peraturan daerah Kota Balikpapan;

5) Penegakan Peraturan Daerah dan Peraturan Walikota dalam rangka peningkatan ketertiban dan ketenteraman di Kota Balikpapan; dan

6) Penindakan, penyelidikan, monitoring, dan penyegelan serta pemusnahan barang hasil penertiban.

\section{e. Sosial}

Penerapan SPM bidang sosial di Kota Balikpapan didasarkan pada ketentuan Peraturan Menteri Sosial Republik Indonesia Nomor 129/HUK/ 2008 Tentang Standar Pelayanan Minimal (SPM) Bidang Sosial Daerah Provinsi Dan Daerah Kabupaten/Kota dan Keputusan Menteri Sosial Republik Indonesia Nomor 80/HUK/2010 tentang Panduan Perencanaan Pembiayaan Pencapaian Standar Pelayanan Minimal (SPM) Bidang Sosial Daerah Provinsi dan Daerah Kabupaten/Kota. 
Dalam rangka pelaksanaan atau penerapan SPM yang telah ditetapkan tersebut, Kementerian Sosial menerbitkan Keputusan Menteri Sosial Republik Indonesia Nomor 80/HUK/2010Tentang Panduan Perencanaan Pembiayaan Pencapaian Standar Pelayanan Minimal (SPM) Bidang Sosial Daerah Provinsi dan Daerah Kabupaten/Kota. Dalam Kepmensos tersebut diuraikan batasan-batasan dari Penyandang Masalah Kesejahteraan Sosial (PMKS) yang merupakan obyek dari penyelenggaraan kesejahteraan sosial dan prasayarat minimal yang harus dipenuhi dalam rangka pelaksanaan SPM tersebut, seperti prosedur bantuan sosial bagi korban bencana, prosedur evakuasi korban bencana, komponen-komponen kegiatan yang harus dilakukan dalam menangani PMKS, dan banyak norma, standar atau prosedur latau kriteria lain terkait pelaksanaan SPM bidang sosial .

Seharusnya jika mengikuti Surat Menteri Sosial RI Nomor C/C.14/SJ/V-2010/MS perihal Peraturan Daerah Tentang Perencanaan Pembiayaan Pencapaian Standar Pelayanan Minimal (SPM) Bidang Sosial di Daerah Provinsi dan Kabupaten/Kota, maka penerapan SPM bidang sosial di Kota Balikpapan juga berpedoman pada peraturan daerah tersebut, namun dalam penelusuran penelitian peraturan daerah tersebut tidak ditemukan, yang ada hanya Peraturan Gubernur Kalimantan Timur Nomor 13 Tahun 2012 tentang Perencanaan Pencapaian Standar Pelayanan Minimal Bidang Sosial Provinsi Kalimantan Timur. Kebelakuan peraturan gubernur tersebut hanya terbatas pada ruang lingkup kerja Dinas Sosial Provinsi Kalimantan Timur, tidak untuk dijadikan pedoman bagi kabupaten/kota di wilayah Provinsi Kalimantan Timur.

Capaian SPM Bidang Sosial Kota Balikpapan selama kurun waktu 2012-2014, secara ringkas adalah:

1) Pelaksanaan Program/Kegiatan Bidang Sosial, rata-rata adalah $62,71 \%$ (2 indikator)

2) Penyediaan Sarana dan Prasarana Sosial, rata-rata adalah $100 \%$ (2 indikator)

3) Penanggulangan Korban, adalah $128,85 \%$ (2 indikator)

4) Pelaksanaan dan Pengembangan Jaminan Sosial bagi Penyandang Cacat, dll, rata-rata adalah $21,81 \%$ (1 indikator)

\section{Kabupaten Berau}

\section{a. Pendidikan}

Dasar yang digunakan dalam SPM bidang pendidikan dasar adalah Peraturan Menteri Pendidikan Nasional Nomor 15 Tahun 2010 Tentang Standar Pelayanan Minimal Pendidikan Dasar Di Kabupaten/Kota sebagaimana dirubah dengan Permendikbud Nomor 23 Tahun 2013 Tentang Perubahan Atas Peraturan Menteri Pendidikan Nasional Nomor 15 Tahun 2010 Tentang Standar Pelayanan Minimal Pendidikan Dasar Di Kabupaten/Kota. Dalam Permendikbud tersebut penyelenggaraan pelayanan pendidikan meliputi 27 indikator.

Melihat data pencapaian SPM bidang Pendidikan di Kabupaten Berau, tampak bahwa belum semua target pencapaian SPM terpenuhi, terutama untuk pelayanan pendidikan dasar oleh Kabupaten Berau, beberapa tenaga pengajar belum sepenuhnya memiliki kualifikasi akademik S1 atau DV serta memiliki sertifikat pendidik dan belum semua sekolah pendidikan dasar (SD/MI dan SMP/MTS) memiliki laboratorium sebagaimana dipersyaratkan dalam SPM. Pun demikian dengan persoalan belum terpenuhinya kuantitas rasio guru dan siswa di setiap jenjang pendidikan di Kabuapten Berau.

Namun demikian, pencapaian target SPM bidang pendidikan saat ini telah membawa dampak yang positif bagi peningkatan kualitas pelayanan publik dan kepuasan masyarakat. Lebih dari pada itu, komitmen Dinas Pendidikan Pemerintah Kabupaten Berau dalam memenuhi SPM bidang pendidikan harus mendapatkan apresiasi.

Adapun capaian SPM Bidang Pendidikan Kabupaten Berau dalam kurun waktu 2013-2015 adalah:

1) Pelayanan dasar yang dilaksanakan oleh kabupaten rata-rata selama 2011-2015 adalah $80,89 \%$ (14 indikator)

2) Pelayanan dasar yang dilaksanakan satuan pendidikan kabupaten rata-rata selama 2011-2015 adalah $87,46 \%$ (13 indikator)

Persentase rata-rata diperoleh dari nilai average capaian per indikator per jenjang pelayanan (SD, SMP, SMA). 


\section{b. Kesehatan}

Mengacu pada Peraturan Menteri Kesehatan RI No. 741/MENKES/PER/VII/2008 tentang Standar Pelayanan Minimal Bidang Kesehatan di Kabupaten/Kota, terdapat 18 indikator standar pelayanan minimal yang harus dipenuhi oleh SKPD yang bertanggungjawab di bidang kesehatan. Indikator SPM tersebut terdiri atas beberapa jenis pelayanan, yaitu:

1) Pelayanan kebutuhan dasar;

2) Pelayanan kesehatan rujukan;

3) Penyelidikan epidemologi dan penanggulangan luar biasa;

4) Promosi kesehatan dan pemberdayaan masyarakat

\section{c. Kesehatan}

Mengacu pada Peraturan Menteri Kesehatan RI No. 741/MENKES/PER/VII/2008 tentang Standar Pelayanan Minimal Bidang Kesehatan di Kabupaten/Kota, terdapat 18 indikator standar pelayanan minimal yang harus dipenuhi oleh SKPD yang bertanggungjawab di bidang kesehatan. Indikator SPM tersebut terdiri atas beberapa jenis pelayanan, yaitu:

1) Pelayanan kebutuhan dasar;

2) Pelayanan kesehatan rujukan;

3) Penyelidikan epidemologi dan penanggulangan luar biasa;

4) Promosi kesehatan dan pemberdayaan masyarakat

Keempat jenis pelayanan ini masing-masing memiliki indikator yang pada level kabupaten/kota diintegrasikan pada rencana strategis SKPD dengan target capaian tertentu di tahun 2015. Berikut adalah indikator SPM Dinas Kesehatan Kabupaten Berau termasuk beberapa kegiatan dinas yang menjadi pendukung kegiatan pencapaian SPM.

Capaian SPM Bidang Kesehatan Berau secara ringkas di Tahun 2015 adalah:

1) Peningkatan keselamatan ibu dan anak, $88,33 \%$ (6 indikator)

2) Peningkatan pelayanan kesehatan anak balita $90 \%$ (1 indikator)

3) Pencegahan dan penanggulangan penyakit menular 100\% (2 indikator)

4) Pelayanan kesehatan penduduk miskin, $100 \%$ (1 indikator)

5) Perbaikan gisi masyarakat, $100 \%$

6) Upaya kesehatan masyarakat, $100 \%$

7) Peningkatan keselamatan ibu melahirkan dan anak, $70 \%$ (1 indikator)

8) Pelayanan kesehatan penduduk miskin, $89,21 \%$ (1 indikator)

9) Promosi kesehatan dan pemberdayaan masyarakat, $80 \%$ (1 indikator)

\section{d. Pekerjaan Umum}

Penerapan SPM bidang pekerjaan umum dan penataan ruang di Kabupaten Berau didasarkan pada ketentuan Peraturan Menteri Negara PU Nomor 01 Tahun 2014 tentang Standar Pelayanan Minimal Bidang Pekerjaan Umum dan Penataan Ruang Kabupaten/Kota.

Pada Pasal 7 ayat (1) Permen PU tersebut dicantumkan bahwa terdapat 5 jenis pelayanan dasar yaitu sumber daya air, jalan, cipta karya, jasa konstruksi, dan penataan ruang.

Capaian SPM Pekerjaan Umum Kabupaten Berau pada Tahun 2015 adalah:

1) Cakupan pelayanan air bersih mencapai $45 \%$ (1 indikator)

2) Sarana dan Prasarana Jalan yang memadai, mencapai 82,5\% di 12 kecamatan (1 indikator)

3) Akses jalan kawasan produksi, mencapai $80 \%$ (1 indikator)

4) Lingkungan Pemukiman kumuh dan rumah layak huni, $39,49 \%$ (2 indikator)

Luas irigasi, mencapai $75,98 \%$ (1 indikator)

\section{e. Perumahan dan Tata Ruang}

Standar Pelayanan Minimal terkait dengan perumahan, mengacu pada Peraturan Menteri Negara Perumahan Rakyat Nomor 22/PERMEN/M/2008 tentang Standar Pelayanan Minimal Bidang Perumahan Rakyat Daerah Provinsi dan Daerah Kabupaten/Kota. Di Kabupaten Berau bidang perumahan merupakan tanggung jawab dari SKPD Perumahan dan Tata Ruang yang memiliki program terkait pencapaian SPM bidang perumahan dan tertuang pada rencana strategis dinas 2011-2015. 
Capaian SPM Perumahan dan Tata Ruang Kabupaten Berau pada Tahun 2015 adalah:

1) Cakupan ketersediaan rumah layak huni, mencapai $100 \%$

2) Cakupan layanan rumah layak huni yang terjangkau, mencapai $70 \%$

Cakupan lingkungan yang sehat dan aman yang didukung PSU, mencapai $100 \%$.

\section{f. Satuan Polisi Pamong Praja}

Ketentuan SPM untuk urusan ketentraman, ketertiban umum, dan perlindungan masyarakat masih berpedoman pada Peraturan Menteri Dalam Negeri RI Nomor 62 Tahun 2008 tentang Standar Pelayanan Minimal Bidang Pemerintahan Dalam Negeri di Kabupaten/Kota sebagaimana diubah dengan Permendagri Nomor 69 Tahun 2012 Tentang Perubahan Atas Peraturan Menteri Dalam Negeri Nomor 62 Tahun 2008 Tentang Standar Pelayanan Minimal Bidang Pemerintahan Dalam Negeri Di Kabupaten/Kota.

Satuan Polisi Pamong Praja Kabupaten Berau telah menerapkan sebagian indikator SPM yang ditetapkan dengan program-program yang termuat di dalam renstra SKPD antara lain:

1) Peningkatan keamanan dan kenyamanan lingkungan melalui:

a) Penyiapan tenaga pengendali keamanan dan kenyamanan lingkungan

b) Pembangunan pos jaga/ronda

c) Pelatihan pengendalian dan keamanan dan kenyamanan lingkungan

d) Pengendalian kebisingan dan gangguan dari kegiatan masyarakat

e) Pengendalian keamanan lingkungan

f) Monitoring dan evaluasi pelaporan

2) Program pemeliharaan kamtrantibmas dan pencegahan tindak kriminal:

a) Pengawasan, pengendalian, dan evaluasi kegiatan polisi pamong praja;

b) Peningkatan kerjasama dengan aparat keamanan dalam teknik pencegahan kejahatan

c) Kerjasama pengembangan kemampuan aparat Polisi Pamong Praja dengan TNI/POLRI dan Kejaksaan

d) Peningkatan kapasitas aparat dalam rangka pelaksanaan siskamswakarsa daerah

e) Monitoring, evaluasi dan pelaporan

3) Program pemberdayaan masyarakat untuk menjaga ketertiban dan keamanan

a) Pembentukan satuan keamanan lingkungan di masyarakat

4) Program peningkatan pemberantasan penyakit masyarakat

\section{Kabupaten Kutai Kartanegara}

\section{a. Pendidikan}

SPM bidang pendidikan didasarkan pada Peraturan Menteri Pendidikan Nasional Nomor 15 Tahun 2010 Tentang Standar Pelayanan Minimal Pendidikan Dasar Di Kabupaten/Kota sebagaimana dirubah dengan Permendikbud Nomor 23 Tahun 2013 Tentang Perubahan Atas Peraturan Menteri Pendidikan Nasional Nomor 15 Tahun 2010 Tentang Standar Pelayanan Minimal Pendidikan Dasar Di Kabupaten/Kota.

Kategori SPM bidang pendidikan dasar terdapat 27 nilai target capaian SPM. Untuk kategori SD, indikator SPM yang terlaksana sebanyak 11 indikator, dengan tingkat ketidaktercapaian sebanyak 11 indikator. Kemudian untuk kategori MI tercapai sebanyak 8 indikator, denga ketidaktercapain sebanyak 14 indikator. SMP tercapai sebanyak 11 indikator dan yang tidak tercapai sebanyak 11 indikator. Untuk kategori MTs tingkat ketercapaian sebanyak 7 indikator dan ketidaktercapaian sebanyak 15 indikator.

Jika diprosentasikan, maka hasil capaian SPM Bidang Pendidikan adalah:

a) Kategori $\mathrm{SD}$, tingkat ketercapaian berada diangka 50 persan dan ketidak tercapaian diangka 50 persen.

b) Kategori MI prosentase ketercapaian sebanyak 36 persen, dan ketidaktercapian sebanyak 64 persen.

c) Kategori SMP tingkat ketercapaian SMP sebanyak 50 persen dan ketidaktercapaian sebanyak 50 persen.

d) MTs tingkat ketercapaian sebanyak 32 persen dan tingkat ketidaktercapainnya 68 persen.

Secara umum pencapaian SPM pada semua jenjang pendidikan yang ada (SD/MI, SMP/MTs) 
tahun 2014 di kabupaten Kutai Kartanegara mengalami peningkatan dari tahun sebelumnya. Indikator SPM yang paling banyak belum terpenuhi dengan tingkat kesenjangan yang tinggi bervariasi menurut jenjang pendidikan. Di jenjang SD/MI, indikator paling banyak tidak terpenuhi adalah tentang pengawas sekolah, ketersediaan buku teks, dan supervisi kepala sekolah. di jenjang SMP/MTs indikator SPM yang paling banyak belum terpenuhi adalah tersedianya ruang laboratorium yang dilengkapi dengan meja dan kursi untuk 36 peserta didik dan minimal satu set peralatan praktek IPA untuk demonstrasi dan eksperimen, ketersediaan buku teks, dan supervisi kelapa sekolah.

Salah satu visi Pemerintah Kabupaten kutai Kartanegara adalah meningkatkan kualitas dan daya saing menuu sumber daya manusia yang unggul, beriman dan bertaqwa kepada Tuhan Yang Maha Esa. Sehingga pendidikan di kabupaten kutai kartanegara menjadi salah satu prioritas pembangunan. Dengan luas wilayah yang jauh antar satu desa dengan desa lainnya, kecamatan dengan pusat pemerintahan maka sarana dan prasana pendidikan menjadi sangat krusial bagi pencapain visi tersebut terlebih lagi ketersediaan tenaga pendidik dan kependidikan yang kompeten dan pemerataan akses bagi siswa. Sehingga pemertaa pembaungan sektor pendidikan perlu lebih mengoptimalkan pelibatan peran serta masyarakat dan multistakholder sebagai kebijakan alternatif yang sangat penting dan menentukan capaian keberhasilan program pendidikan 12 tahun bagi masyarakat.

Keberadaan sekolah swasta sekolah swasta mempunyai peran yang cukup besar dalam pemenuhan indikator SPM dan keberadaan CSR perusahaan swasta juga memiliki kontribusi yang besar bagi sekolah terhadap pemenuhan SPM di kabupaten kutai kartanegara.

\section{b. Kesehatan}

Tersedianya fasilitas dan kualitas kesehatan merupakan bagian salah satu faktor utama meningkatkan derajat kesehatan penduduk. Berbagai aspek pendukung peningkatan kualitas kesehatan masyarakat seperti ketersediaan sarana dan prasarana kesehatan yang moderan kualitas dan kuantitas tenaga kesehatan sampai anggaran kesehatan mutlak diperlukan untuk menndorong kesehatan yang lebih baik. Semakin mudah masyarakat mendapatkan pemenuhan kesehatan akan memparcepat pembagunan suatu daerah. Pelayanan kesehatan yang maksimal merupakan prasyarat mutlak bagi pembangunan sebuah daerah.

Standar Pelayanan Minimal (SPM) Bidang Kesehatan telah diatur di dalam Peraturan Menteri Kesehatan RI Nomor 741/MENKES/Tahun 2008 Tentang Standar Pelayanan Minimal Bidang Kesehatan di Kabupaten/Kota. SPM kesehatan memuat 18 indikator dengan 4 jenis pelayanan dasar.

Capaian SPM Bidang Kesehatan Kabupaten Kutai Kartanegara adalah:

a) Dari 22 indikator SPM Bidang Kesehatan, 17 Indikator berstatus tercapai, dan hanya 5 indikator yang tidak tercapai

b) Berdasarkan tingkat efektifitas, capaian SPM Bidang Kesehatan adalah; 50\% sangat efektif, 23\% efektif, $13 \%$ cukup efektif, dan $14 \%$ tidak efektif.

Penerapan SPM yang efektif tidak bisa dilepaskan dari peran sarana dan prasarana kesehatan yang ada di kabupaten kutai kartanegara. Salah satunya yang paling signifikan pengaruhnya adalah prasarana kesehatan. Setidaknya jika mengacu pada SNI 03-1733-1989, rasio Puskesmas di kabupaten kutai kartanegara adalah 1:3.538 penduduk. Mengacu pada rasio tersebut maka Puskesmas di kabupaten kutai kartanegara sangat layak, karena melebihi jumlah sesuai standar. Idealnya, Puskesmas Pembantu (Pustu) memiliki standar rasio 1:30.000. Jika jumlah Pustu Kabupaten Kutai Kartanegara ada 177 unit pada tahun 2015.

\section{c. Pekerjaan Umum}

Terdapat 3 (tiga) jenis layanan dasar SPM bidang pekerjaan umum, yaitu; a) kebutuhan air baku, b) penyediaan kualitas jalan, dan c) konektifitas wilayah kabupaten/kota. 3 (tiga) layanan dasar yang harusnya dicapai melalui 3 (tiga) indikatornya 'terlihat' tidak tercapai dengan pencantuman huruf NA sebagai gambaran atas tidak tersedianya data capaian. Data yang belum tersedia terjadi sebagai dampak dari pengolahan data kegiatan yang belum terkompilasi dengan baik. Namun demikian, sebagaimana telah disampaikan sebelumnya, walaupun ketiga indikator SPM tidak tampak datanya, namun hampir semua indikator urusan sebagaimana tersebut di dalam renstra bina marga yang berjumlah 30 (tiga puluh) dan urusan sumber daya air yang berjumlah 20 (dua puluh), senyatanya telah mengacu kepada indicator SPM. 
Walaupun capaian indikator SPM belum ada, bukan berarti pelaksanaan SPM tidak berjalan, karena kegiatan yang sudah dijalankan 'berkarakteristik' indikator SPM. Kondisi seperti ini terjadi dikarenakan data-data kegiatan masih 'terserak' sebagai data yang berdiri sendiri, atau belum terformulasi sebagai data SPM sebagaimana data-data tersebut seharusnya terolah melalui rumus-rumus perhitungan SPM yang telah ditetapkan.

Berdasarkan hasil penggalian data baik melalui dokumen maupun wawancara pada Dinas Pekerjaan Umum dan Sumber daya air yang mengampu SPM bidang Pekerjaan Umum dan penataan Ruang dengan Sub Bidang Sumber Daya Air didapatkan gambaran bahwa penyusunan SPM belum dilaksanakan secara maksimal dalam penerapannya. SPM di dinas pekerjaan umum pernah disusun di tahun 2013 (berdasarkan data yang belum lengkap), setelah itu SPM tidak pernah dibuat lagi, sebagaimana yang disampaikan oleh bapak Hendra selaku narasumber pada saat wawancara: "SPM, jalan tapi tidak maksimal karena proses yang ada di kita sendiri. Kita pernah bikin tahun 2013, yang kita lakukan kemaren penerjemahan 100 persen dari pusat belum paham, 100 persen itu dari mana?".

\section{d. Perumahan dan Tata Ruang}

Dinas Cipta Karya mengampu dua bidang SPM, yakni bidang Pekerjaan Umum dan Penataan Ruang (Sub Bidang Cipta Karya, Sub Bidang Penataan Ruang) dengan mengacu kepada Peraturan Menteri Pekerjaan Umum Nomor 01/PRT/M/2014 tentang SPM bidang Pekerjaan Umum dan Penataan Ruang serta SPM bidang Perumahan Rakyat dengan mengacu kepada Peraturan Menteri Perumahan Rakyat No. 22/PERMEN/M/2008 tentang Standar Pelayanan Minimal bidang Perumahan Rakyat daerah Provinsi dan daerah Kabupaten/Kota. Dengan adanya 'penggabungan' dua bidang SPM dalam Dinas Cipta karya dan Tata Ruang, maka terdapat 11 (sebelas) jenis layanan dasar dan 16 (enam belas) indikator yang menjadi tugas dinas cipta karya dan tata ruang.

Rentang waktu tiga tahun (2013-2015), target capaian yang terkait SPM cenderung mengalami kenaikan, walaupun ada indikator yang target capaiannya di dua tahun terakhir bersifat konstan. Di samping yang naik dan konstan, terdapat juga satu indikator yang mengalami penurunan di beberapa tahun berikutnya walaupun penurunan itu tidak sangat signifikan.

Patut untuk diapresiasi dari penetapan target di RPJMD adalah adanya keberanian untuk menetapkan target di atas target nasional sebelum batas waktu pencapaian. Begitupun terkait adanya target indikator yang sudah mendekati target nasional, padahal batas waktu pencapaian masih jauh, tentunya juga menjadi apresiasi tersendiri. Tentunya keberanian tersebut merupakan hal yang luar biasa, karena pasti dalam penetapannya sudah melalui perhitungan dan pertimbangan yang cukup komperhensif.

Untuk mengetahui tentang seberapa besar pencapaian indikator SPM bidang pekerjaan umum, tata ruang dan perumahan rakyat, berikut profil SPM yang menggambarkan capaian target indikator SPM;

a) Dari 16 indikator yang ditetapkan, dalam rentang waktu 3 (tiga) tahun cenderung terjadi kenaikan angka capaian target, walaupun ada juga yang tidak mengalami kenaikan alias konstan.

b) Sampai dengan tahun 2016, 7 (tujuh) indikator masih harus terus bergerak naik untuk memenuhi target nasional di tahun 2019. Sementara itu, terdapat 2 (dua) indikator sudah memenuhi target nasional.

c) Tiga indikator 'lepas' dari target capaian karena sudah terjadi 'alih' kewenangan pencapaian ke Badan pelayanan Perijinan Terpadu sebagai kewajiban pelayanan satu pintu.

d) Sementara dua indikator tidak menetapkan targetnya di 2016, dan 2 (dua) target indikator datanya tidak tersedia sama sekali alias not available (NA).

e) Satuan Polisi Pamong Praja

Standar Pelayanan Minimal (SPM) bidang Pemerintahan Dalam Negeri diatur dalam Peraturan pemerintah Tahun 2005 tentang pedoman penyusunan dan penetapan SPM serta Peraturan Menteri Dalam Negeri nomor 62 tahun 2008 tentang SPM bidang pemerintahan dalam negeri di kab/kota yang diubah dengan Permendagri nomor 69 tahun 2012 tentang perubahan penyususnan SPM.

Dalam pedoman SPM bidang pemerintahan dalam negeri di satuan polisi pamong praja meliputi tiga indikator yaitu:

a) Cakupan penegakan peraturan daerah dan peraturan kepala daerah di kabupaten/kota.

b) Cakupan patroli siaga ketertiban umum dan ketentraman masyarakat.

c) Cakupan rasio petugas perlindungan masyarakat (linmas) di kabupaten/kota. 
SPM pemerintahan dalam negeri yang dilaksanakan oleh Satpol PP Kabupaten Kutai Kartanegara belum terlaksana semuanya hal ini diakibatkan belum dituliskannya laporan SPM oleh Satpol PP kabupaten kutai kartanegara. Salahsatu permaslahn utamnya adalah lemahnya pemahaman terkait penerapan SPM. Pemeahaman satpol pp kukar dalam hal ini aparaturnya masih perlu perhatian serius sehingga implementasi terhadap pencapaian SPM berjalan kurang optimal, hal ini didasarkan terhadap indikator SPM yang belum dibubukan dalam laporan SPM.

\section{e. Sosial}

SKPD Dinas Sosial mengampu SPM bidang sosial. Terdapat 4 (empat) Jenis layanan dasar dengan tujuh indikator pencapaian yang harus dilaksanakan dan dicapai oleh Dinas sosial sebagaimana tersebut di dalam Peraturan Menteri Sosial No 129 Tahun 2008 mengenai Standar Pelayanan Minimal (SPM) Bidang Sosial Daerah Provinsi dan Daerah kabupaten/Kota. Dinas sosial Kabupaten Kutai Kertanegara, dari tahun 2013 secara rutin telah membuat SPM dan secara rutin juga telah menyampaikan dokumen SPM ke bagian organisasi.

\section{f. Sosial}

SKPD Dinas Sosial mengampu SPM bidang sosial. Terdapat 4 (empat) Jenis layanan dasar dengan tujuh indikator pencapaian yang harus dilaksanakan dan dicapai oleh Dinas sosial sebagaimana tersebut di dalam Peraturan Menteri Sosial No 129 Tahun 2008 mengenai Standar Pelayanan Minimal (SPM) Bidang Sosial Daerah Provinsi dan Daerah kabupaten/Kota. Dinas sosial Kabupaten Kutai Kertanegara, dari tahun 2013 secara rutin telah membuat SPM dan secara rutin juga telah menyampaikan dokumen SPM ke bagian organisasi.

Sebagaimana yang disampaikan oleh Kasubbag Penyusunan Program dalam wawancara penggalian data "Ya. dulunya kami tidak tahu......karena di pemda pun belum tahu SPM secara keseluruhan...mulai 2013 ..setiap tahun kami kumpulkan melalui bagian organisasi". Khusus tahun ini, laporan SPM belum tersusun, hal ini karena adanya 'pemberitahuan yang belum tertindak lanjuti' bahwa akan ada Peraturan Menteri Sosial yang baru terkait penetapan indikator bidang sosial, namun hingga wawancara dilakukan (bulan juni) belum ada tindak lanjut dari pemberitahuan tersebut, sehingga membuat kebingungan Dinas Sosial dalam menyusun laporan SPM, lebih lanjut disampaikan "Laporan semester harusnya dibikin (2016) menunggu draft indikator yang baru sudah dibikin, Cuma berapa besaran targetnya belum diketahui, dan ditargetkan tahun berapa kami belum tahu".

Untuk mengetahui tentang penerapan dan pencapaian SPM, petunjuk 'termudah' untuk mengetahuinya adalah melalui keberadaan indikator SPM di dalam dokumen strategis pemerintah daerah dan SKPD. Untuk dokumen strategis pemerintah daerah terepresentasikan melalui dokumen RPJMD. Dalam dokumen RPJMD kita dapat melihat, apakah indikator pencapaian SPM sebagaimana tersebut di dalam Peraturan menteri Sosial No. 129/HUK/2008 tentang Standar Pelayanan Minimal (SPM) Bidang Sosial Daerah Provinsi dan Daerah Kabupaten/Kota sudah terakomodasi ataukah belum. Terkait target pencapaian indikator yang ditetapkan, cenderung mengalami peningkatan di setiap tahunnya atau di dua tahun terakhir. Jika dibandingkan dengan capaian target nasional, target tersebut ada yang melebihi target nasional.

Pada tahun 2015 sebagai batas tahun pencapaian indikator, dari 7 (tujuh) indikator yang telah ditetapkan prosentase capaiannya:

a) 6 (enam) diantaranya telah melampaui target yang ditetapkan nasional.

b) ada 1 (satu) indikator yang belum mencapai standar nasional, yakni terkait indikator prosentase PMKS skala Kab/Kota yang menerima program pemberdayaan sosial melalui kelompok Usaha

Bersama (KUBE) atau kelompok sosial ekonomi sejenis lainnya.

Dari hasil keseluruhan pencapaian indikator SPM, pihak Dinsos melalui Kasubag Sungramnya mengatakan bahwa yang tidak kalah penting dari pencapaian SPM adalah terkait kualitas pencapaian, bukan hanya berdasar pencapaian angka-angka saja, sebagaimana yang beliau sampaikan "Capaian indikator tercapai $100 \%$ sesuai aturan...kualitas pencapaian mungkin yang akan menjadi evaluasi ke depan. Tapi kalau hanya target operasional... $80 \%$ sudah ada perubahan perilaku".

\section{Kota Samarinda}




\section{a. Pendidikan}

Standar Pelayanan Minimal (SPM) Bidang Pendidikan Dasar diatur di dalam Permendikbud Nomor 23 Tahun 2013 tentang Perubahan Atas Peraturan Menteri Pendidikan Nasional Nomor 15 Tahun 2010 Tentang Standar Pelayanan Minimal Pendidikan Dasar di Kabupaten/Kota. Pada dasarnya, rencana pencapaian SPM sebagian besar telah tergambar dalam program dan kegiatan SKPD terkait. Dalam bidang pendidikan misalnya, Dinas Pendidikan Kota Samarinda sebagai pengampu SPM bidang pendidikan dasar telah memasukkan rencana pencapaian SPM bidang pendidikan di Kota Samarinda dalam Renja SKPD Dinas Pendidikan yang dilaksanakan dalam bentuk program dan kegiatan seperti

a) Program wajib belajar pendidikan dasar dua belas tahun;

b) Program peningkatan mutu pendidik dan tenaga kependidikan;

c) Program manajemen pelayanan pendidikan;

d) Program peningkatan sarana dan prasarana penunjang pendidikan.

Hampir sebagian indikator SPM mengalami kenaikan yang cukup signifikan per tahunnya contohnya seperti indikator jumlah peserta didik dalam satu rombel yang meningkat dari angka 12,16 $\%$ menjadi 80,21 \% untuk level SD dan meningkat dari angka $0 \%$ menjadi 90,66 \% untuk level SMP. Selain itu ketersediaan jumlah guru SD di dalam rombel maupun satuan pendidikan juga meningkat dari 52,25\% pada tahun 2013 dan 2014 menjadi $100 \%$ pada tahun 2015. Ketersediaan guru untuk setiap mata pelajaran di tingkat SMP yang meningkat dari angka 24,69\% pada tahun 2013 dan 2014 menjadi $100 \%$ pada tahun 2015. Ketersediaan pengawas sekolah pun mengalami kenaikan yang sangat signifikan dimana pada tahun 2013 dan 2014 pencapaiannya hanya $0 \%$ namun meningkat menjadi 79,71 $\%$ pada tahun 2015. Hal ini menunjukkan bahwa Dinas Pendidikan Kota Samarinda cukup serius dalam rangka meningkatkan kualitas pelayanan publik bidang pendidikan kepada masyarakat.

Namun beberapa indikator lain banyak yang belum memenuhi target seperti indikator ketersediaan buku teks untuk level SD dan SMP, supervisi kepala sekolah, jumlah guru yang memiliki kualifikasi akademik tertentu dan sertifikat pendidik dan lain lain.

\section{b. Kesehatan}

Standar Pelayanan Minimal sebagaimana diatur dalam Pasal 11 ayat (4) Undang-Undang Nomor 32 Tahun 2004 tentang Pemerintahan Daerah merupakan ketentuan tentang jenis dan mutu pelayanan dasar dalam penyediaan kebutuhan dasar masyarakat dan merupakan urusan wajib daerah yang berhak diperoleh setiap warga secara minimal. Dalam bidang kesehatan, ketentuan Standar Pelayanan Minimal (SPM) diatur di dalam Peraturan Menteri Kesehatan RI Nomor 741/MENKES/Tahun 2008 tentang Standar Pelayanan Minimal Bidang Kesehatan di Kabupaten/Kota. SPM Bidang Kesehatan di Kab/Kota mencakup 4 (empat) jenis pelayanan terdiri dari :

1) Pelayanan Kesehatan Dasar;

2) Pelayanan Kesehatan Lanjutan;

3) Penyelidikan Epidemiologi dan Penanggulangan KLB;

4) Promosi Kesehatan dan Pemberdayaan Masyarakat.

Berdasarkan hasil capaian, terlihat bahwa hampir sebagian besar indikator SPM telah mencapai $100 \%$ kecuali untuk beberapa indikator yang masih jauh dari target seperti cakupan neonatal dengan komplikasi yang ditangani yang terealisasi di angka $39 \%$ dari target $80 \%$ dan cakupan pelayanan anak balita yang terealisasi dia angka $47 \%$ dari target $90 \%$.

\section{c. Pekerjaan Umum dan Tata Ruang}

Kinerja pemerintah daerah Kota Samarinda dalam memberikan pelayanan dasar yang paling minimal di bidang Pekerjaan Umum dan Penataan Ruang diatur dengan Permen PU No. 14/PRT/M/2010 yang mengatur mengenai target capaian SPM di daerah dalam kurun waktu tahun 20102014 dengan 23 jumlah indikator. Setelah habis masa berlakunya kementerian PU kembali mengeluarkan peraturan terbaru mengenai SPM dengan No. 01/ PRT/M/2014 dengan batas waktu capaian 2014-2019 dengan 16 indikator dengan asumsi bahwa indikator yang sebelumnya telah ditargetkan dapat dicapai oleh daerah dimana terdapat penyederhanaan indikator pada jenis layanan dasar jaringan jalan dari 5 indikator menjadi 2 indikator. Penyederhanaan indikator pada penataan bangunan dan lingkungan dari 2 menjadi 1 indikator serta penyederhanaan jenis layanan penataan ruang 
dari 5 menjadi 2 indikator. Namun target dari kedua Permen tersebut untuk indikator yang sama tidak berbeda, sehingga dalam tabel berikut ini tetap memuat capaian tahun-tahun sebelumnya.

Berdasarkan hasil wawancara dengan Kasubbag Perencanaan Program Dinas Cipta Karya dan Tata Kota serta Dinas Bina Marga bahwa sebagai SKPD penanggung jawab SPM bidang Pekerjaan Umum dan Penataan Ruang memang belum menyusun laporan penerapan dan pencapaian SPM bidang Pekerjaan Umum dan Penataan Ruang dan belum melaporkannya kepada Bagian Pembangunan Setda Kota Samarinda, namun terdapat beberapa data pada renstra, RKA dan Lakip yang dapat dijadikan rujukan dalam menganalisis dan mengevaluasi hasil pelaksanaan SPM serta berdasarkan pengisian tabel Capaian SPM yang terdapat dalam kuesioner yang diberikan.

Capaian SPM Bidang Pekerjaan Umum dan Tata Ruang Kota Samarinda, rata-rata selama 20112015 adalah:

a) Penyediaan air baku, rata-rata mencapai $27,68 \%$ (2 indikator)

b) Penyediaan jalan untuk masyarakat, rata-rata mencapai $41,75 \%$ (2 indikator)

c) Penyediaan air minum, rata-rata mencapai 16,35 (1 indikator)

d) Penyediaan sanitasi, rata-rata mencapai $36,96 \%$ (5 indikator)

e) Penataan bangunan dan lingkungan, rata-rata mencapai 47,75\% (1 indikator)

f) Penanganan pemukiman kumuh dan perkotaan, rata-rata mencapai $2 \%$ (1 indikator)

Pengembangan sistem informasi jasa konstruksi, rata-rata mencapai 12 (1 indikator)

\section{d. Satpol PP}

Dalam UU Nomor 23 Tahun 2014, ketentraman, ketertiban umum dan perlindungan masyarakat merupakan salah satu urusan pemerintahan wajib yang berkaitan dengan pelayanan dasar. Ketentuan SPM untuk urusan ini berpedoman pada Peraturan Menteri Dalam Negeri Nomor 69 Tahun 2012 tentang Perubahan Atas Peraturan Menteri Dalam Negeri Nomor 62 Tahun 2008 tentang Standar Pelayanan Minimal Bidang Pemerintahan Dalam Negeri di Kabupaten/Kota.

Pada dasarnya, rencana pencapaian SPM sebagian besar telah tergambar dalam program dan kegiatan SKPD. Satpol PP Kota Samarinda sebagai pengampu SPM bidang ketentraman, ketertiban umum dan perlindungan masyarakat telah memasukkan rencana pencapaian SPM dalam Renja Satpol PP yang dilaksanakan dalam bentuk program dan kegiatan sebagai berikut :

a) Cakupan penegakan peraturan daerah dan peraturan kepala daerah di kabupaten/kota didukung dengan program peningkatan keamanan dan kenyamanan lingkungan.

b) Cakupan patrol siaga ketertiban umum dan ketentraman masyarakat didukung dengan program pemeliharaan kantrantibmas dan pencegahan tindak kejahatan

c) Cakupan rasio petugas perlindungan masyarakat (linmas) di kabupaten/kota didukng dengan program pemberdayaan masyarakat untuk menjaga ketertiban dan keamanan.

Capaian SPM Satpol PP pada ketiga bentuk program dan kegiatan di atas, adalah mencapai $100 \%$.

\section{e. Sosial}

Dari sisi perencanaan dapat diketahui bahwa rencana pencapaian SPM bidang sosial sudah dimasukkan ke dalam Renja SKPD Dinas Kesejahteraan Sosial yang direalisasikan dalam program dan kegiatan. sehingga secara umum pelaksanaan SPM bidang sosial dinilai telah berhasil meskipun terdapat beberapa kendala. Dari 4 jenis layanan dasar menurut SPM, semuanya telah dilaksanakan dalam bentuk program dan kegiatan yaitu:

a) Pelaksanaan Program/kegiatan bidang sosial didukung dengan program pelayanan dan rehabilitasi sosial dan pelaksanaan pemberdayaan sosial

b) Penyediaan Sarana dan Prasana Sosial didukung dengan Program peningkatan peyanan dan rehabilitasi sosial dan pelaksanaan program pemberian pelayanan dan rehabiltasi panti sosial yang telah diterapkan

c) Penganggulangan Bencana didukung dengan program penanggulangan bencana dan pelaksana program penanggulangan bencana berbasis masyarakat.

d) Pelaksanaan Jaminan Sosial didukung dengan program bantuan dan perlindungan sosial, program pelayanan dan rehabilitasi sosial serta program peningkatan pelayanan dan rehabilitasi panti sosial. 
SPM bidang sosial ini dilaksanakan oleh Dinas Kesejahteraan Sosial Kota Samarinda. Pada bidang Sosial terdapat tujuh indikator yang ditetapkan oleh Kementerian Sosial berdasarkan Peraturan Menteri Sosial No. 129/HUK/2008 tentang Indikator Standar Pelayanan Minimal Bidang Sosial. Dalam peraturan ini ditargetkan baik provinsi maupun kabupaten/kota dapat mencapai target SPM pada tahun 2015. Bahkan Pemerintah Kota Samarinda pun menetapkan Peraturan Walikota Samarinda No. 04 tahun 2011 tentang Standar Pelayanan Minimal Urusan Pemerintah Kota dalam menyelenggarakan pelayanan sosial dasar kepada masyarakat dengan tujuan untuk meningkatkan dan menjamin mutu pelayanan sosial kepada masyarakat. Penerapan SPM merupakan hak dan pelayanan dasar penyandang masalah kesejahteraan sosial (PMKS) yang penyelenggaraannya diwajibkan kepada daerah untuk kesejahteraan sosial.

Capaian SPM Bidang Sosial Kota Samarinda, rata-rata selama 2011-2015 adalah:

a) Pelaksanaan program/kegiatan bisang sosial, rata-rata mencapai $208,24 \%$ (2 indikator)

b) Penyediaan sarana dan Penyediaan sarana dan prasarana sosial, rata-rata mencapai $33,9 \%$ (2 indikator)

c) Penanggulangan korban bencana, rata-rata mencapai 60,73\% (2 indikator)

d) Pelaksanaan Jaminan Sosial, rata-rata mencapai 125,34\% (1 indikator)

\section{Permasalahan dan Solusi Standar Pelayanan Minimal}

SPM pada dasarnya sudah diimplementasikan sejak lama, namun implementasinya masih belum berjalan seperti yang diharapkan. Berbagai kendala dan permasalahan, baik yang berasal dari pihak internal SKPD penanggungjawab masih sering dan selalu terjadi. Identifikasi berbagai pemasalahan disertai solusi yang diharapkan SKPD tergambar pada Tabel berikut ini:

Tabel 2. Identifikasi Masalah dan Solusi Implementasi SPM

\begin{tabular}{|c|c|c|}
\hline Jenis Masalah & Permasalahan & Tindak Lanjut/Solusi \\
\hline Pemahaman SPM & $\begin{array}{c}\text { Belum semua pelaksana SPM, } \\
\text { memahami SPM sebagai sebuah } \\
\text { instrumen yang komprehensif }\end{array}$ & $\begin{array}{c}\text { Perlu penempatan } \\
\text { pegawai yang lebih baik } \\
\text { dan kontinyu }\end{array}$ \\
\hline $\begin{array}{c}\text { Indikator dan Definisi Operasional } \\
\text { (DO) SPM }\end{array}$ & $\begin{array}{c}\text { Tidak semua indikator dapat } \\
\text { dipahami dan mudah dimengerti }\end{array}$ & $\begin{array}{c}\text { Perlu kesepakatan } \\
\text { indikator dan definisi } \\
\text { yang belum jelas atau } \\
\text { sulit dimengerti }\end{array}$ \\
\hline Formulasi & $\begin{array}{l}\text { Tidak semua indikator dapat dihitung } \\
\text { dan menunjukkan kondisi yag logis }\end{array}$ & $\begin{array}{l}\text { Perlu kesepakatan } \\
\text { formulasi yang sulit } \\
\text { dihitung dan kurang } \\
\text { logis }\end{array}$ \\
\hline Data Dasar & $\begin{array}{l}\text { Tidak semua data dasar tersedia dan } \\
\text { data cenderung kurang update }\end{array}$ & $\begin{array}{l}\text { Perlu kejelasan tugas } \\
\text { dan kewenangan pihak } \\
\text { penyedia data }\end{array}$ \\
\hline Penetapan Target SPM & $\begin{array}{c}\text { Karakteristik daerah yang berbeda } \\
\text { menyulitkan daerah untuk } \\
\text { menetapkan target mengacu target } \\
\text { nasional }\end{array}$ & $\begin{array}{c}\text { Meningkatkan } \\
\text { koordinasi dengan } \\
\text { SKPD terkait untuk } \\
\text { penetapan target riil }\end{array}$ \\
\hline Perumusan Program dan Kegiatan & $\begin{array}{c}\text { Disharmoni RPJMD dan Renstra } \\
\text { dengan Permen-dagri No. } 13 \text { Tahun } \\
2006\end{array}$ & $\begin{array}{c}\text { Sinkronisasi antara SPM } \\
\text { dengan dokumen } \\
\text { perencanaan lainnya }\end{array}$ \\
\hline Anggaran & $\begin{array}{l}\text { Penganggaran pada beberapa daerah } \\
\text { belum berorientasi pada SPM }\end{array}$ & $\begin{array}{l}\text { Perlu penerapan e- } \\
\text { costing yang berorientasi } \\
\text { pada SPM }\end{array}$ \\
\hline $\begin{array}{l}\text { Penyiapan Rencana Aksi Daerah } \\
\text { (RAD) }\end{array}$ & $\begin{array}{c}\text { RAD belum dapat diimplementasikan } \\
\text { mengingat sering terjadi perubahan } \\
\text { kebijakan baik di pusat maupun } \\
\text { daerah }\end{array}$ & Review dokumen RAD \\
\hline
\end{tabular}




\begin{tabular}{ccc}
\hline Jenis Masalah & Permasalahan & Tindak Lanjut/Solusi \\
\hline Integrasi SPM dalam Dokumen \\
Perencanaan & $\begin{array}{c}\text { Tidak semua indikator SPM dapat } \\
\text { dengan mudah diintegrasikan dengan } \\
\text { pemenuhan visi dan misi kepala } \\
\text { daerah }\end{array}$ & $\begin{array}{c}\text { Peningkatan Komitmen } \\
\text { antar SKPD dan Kepala } \\
\text { Daerah }\end{array}$ \\
\hline Koordinasi antar Stakeholder Daerah & $\begin{array}{c}\text { Kondisi ego-sektoral di beberapa } \\
\text { daerah masih cukup kuat }\end{array}$ & $\begin{array}{c}\text { Peningkatan komitmen } \\
\text { dan koordinasi antar } \\
\text { stakeholder }\end{array}$ \\
\hline Pembinaan dari & Pembinaan Kementerian belum rutin \\
Kementerian/Lembaga & dan kontinyu & $\begin{array}{c}\text { SKPD pro aktif ke } \\
\text { Kementerian }\end{array}$ \\
\hline
\end{tabular}

Sumber: Hasil Wawancara, 2016

\section{1) Pemahaman SPM}

Ketidakpahaman akan arti penting dan makna adanya SPM pasti akan menghambat penerapan dan pencapaian SPM. Kesamaan semangat dan pola pikir dari aparatur penyelenggara menjadi faktor yang sangat penting dalam menerapkan dan mencapai target SPM. Pola mutasi aparatur sipil yang tidak terkontrol juga menjadi hal yang menghambat pencapaian target SPM. Sebagai contoh di Satpol PP. Aparatur sipil yang telah mendapatkan sosialisasi dan bimbingan teknis, belum lama menerapkan hasil bimbingan teknisnya sudah harus meninggalkan Satpol PP dan diganti dengan aparatur sipil yang belum mendapatkan sosialisasi dan bimbingan teknis SPM bidang ketentraman, ketertiban umum, dan perlindungan masyarakat, sehingga memerlukan waktu lagi untuk mempelajari seluk beluk SPM.

Masalah lain dari pemahaman SPM secara komprehensif, juga ditemukan di Satpol PP. Secara rasio, jumlah pelaksana seksi operasional ketertiban umum dan ketenteraman masyarakat yang berjumlah 147 orang pada tahun 2015 belum cukup untuk melindungi masyarakat Kota Balikpapan yang berjumlah sekitar 713.000. Selain itu, kendala keterbatasan personil disini termasuk keterbatasan satuan petugas linmas yang sedianya warga masyarakat yang disiapkan dan dibekali pengetahuan serta ketrampilan untuk membantu pelaksanaan kegiatan penanganan bencana guna mengurangi dan memperkecil akibat bencana, serta ikut membantu memelihara keamanan, ketentraman, ketertiban masyarakat dan kegiatan sosial kemasyarakatan sebagaimana dimaksud dalam Peraturan Menteri Dalam Negeri Nomor 44 Tahun 2010 tentang Ketentraman dan Perlindungan Masyarakat Dalam Rangka Penegakan Hak Asasi Manusia.

Pemahaman SPM secara komprehensif juga menyangkut pemahaman beberapa indikator dari SPM secara terpadu. Sebagai contoh kasus, pemahaman bidang sosial yang ditetapkan belum dapat sepenuhnya dipahami oleh Dinas Tenaga Kerja dan Sosial Kota Balikpapan karena masih bersifat umum atau tidak dirumuskan dalam indikator yang bersifat operasional. Solusi untuk masalah-masalah seperti adalah dengan melakukan penempatan pegawai atau aparatur sipil secara kontinyu, dan disesuaikan dengan keahlian dan minat aparatur sipil yang ditempatkan.

\section{2) Indikator dan Definisi Operasional SPM}

Perbedaan definisi operasional antara peraturan perundangan yang satu dengan yang lain, sering menjadi masalah dalam penerapan SPM. Sebagai contoh indikator SPM untuk bidang perumahan yang tercantum dalam Permendagri Nomor 54 Tahun 2010 tidak sama dengan indikator SPM yang ada di Peraturan Pemerintah Perumahan Rakyat Nomor 22 tahun 2008 dalam lampiran 1 dan 2. Inkonsistensi ini menyulitkan dinas karena meskipun indikator di kedua peraturan sama tetapi formulasinya berbeda. Implikasinya waktu dan sumberdaya yang dibutuhkan untuk menghitung indikator ini menjadi lebih banyak dan seringkali berimbas pada tidak tercapainya target yang diberikan. Contoh kasus yang lain adalah, beberapa indikator dari SPM bidang sosial yang ditetapkan belum dapat sepenuhnya dipahami oleh Dinas Tenaga Kerja dan Sosial Kota Balikpapan karena masih bersifat umum atau tidak dirumuskan dalam indikator yang bersifat operasional.

Demikian pula halnya dengan Indikator SPM Bidang Kesehatan, terutama pada indikator: Cakupan Pelayanan Kesehatan Dasar Masyarakat Miskin, Cakupan Pelayanan Kesehatan Rujukan Masyarakat Miskin. Indikator ini kurang logis, mengingat angka ideal yang ditargetkan adalah mencapai 
100\%. Kurang logis karena, bagaimana mungkin mengharuskan masyarakat miskin berobat semua $(100 \%)$, agar indikator ini dapat dikatakan baik dan tercapai?.

Masalah lainnya adalah pada jumlah dan tingkat kesulitan penetapan indikator. Contoh kasus adalah pada bidang Pekerjaan Umum. jika dilihat dari jumlah indikator maka sebenarnya indikator SPM bidang pekerjaan umum dan penataan ruang tidak lebih banyak dibanding indikator SPM bidang pendidikan, 14 berbanding 27, namun demikian jika melihat tingkat kesulitan dan jumlah biaya yang harus dikeluarkan tentu saja tidak mudah untuk memenuhi target SPM yang telah ditetapkan. Sifat indikator yang lebih bersifat fisik memaksa ini, dalam contoh kasus di Dinas Pekerjaan Umum Kota Balikpapan, membuat SKPD ini bekerja ekstra untuk mewujudkan kuantitas dan kualitas target SPM yang telah ditetapkan.

Inkonsistensi indikator, tingkat kesulitan indikator yang berbeda, dan indikator yang belum operasional, harus ditindaklanjuti dengan perlunya kesepakatan antara pelaksana SPM dengan SKPD pendukung SPM. Perlu dirumuskan kembali, dan disepakati konsistensi indikator, menggunakan indikator yang mana, di antara peraturan yang dirujuk. Semisal apakah menggunakan Permendagri Nomor 54 Tahun 2010, ataukah menggunakan peraturan menteri di kementerian teknisnya. Hal ini sebenarnya sudah sering didiskusikan, namun belum menjadi dasar. Diskusi sering terjadi saat wawancara pada pertemuan monev baik di provinsi maupun di pusat. Arah diskusi adalah untuk tetap menggunakan DO yang ada dan menampilkan data sesuai kondisi riil di lapangan. Disamping itu, perlu juga penambahan narasi yang menjelaskan secara rinci arti capaian indikator SPM dimaksud.

\section{3) Formulasi}

Beberapa formulasi indikator SPM masih memiliki permasalahan, karena terkadang belum jelas. Kapan harus menggunakan persen, atau nominal, atau hanya jumlah tertentu. Masalah lainnya adalah komponen dalam formulasi juga belum menunjukkan mana yang pembilang dan dan yang mana sebagai penyebut. Masalah yang lain, juga terjadi pada nilai ideal yang dipersyaratkan dalam sebuah indikator SPM. Misalnya pada Bidang Kesehatan; dikenal indikator Cakupan Pelayanan Kesehatan Dasar Masyarakat Miskin, dan Cakupan Pelayanan Kesehatan Rujukan Masyarakat Miskin.

Fornulasinya adalah:

Cakupan Pelayanan Kesehatan Dasar Masyarakat Miskin:

$$
\text { CPKDMM }=\frac{\text { Jumlah Kunjungan Pasien Masykin }}{\text { Jumlah Masy Mikin }} \times 100 \%
$$

Cakupan Pelayanan Kesehatan Rujukan Masyarakat Miskin:

$$
\text { CPKRMM }=\frac{\text { Jlh Kunjungan Pasien Masykin }}{\text { Jumlah masykin Kabupaten } / \text { kota }} \times 100 \%
$$

Formulasi ini, cukup membingungkan pelaksana SPM. Secara matematis, formulasi ini mengharuskan seluruh masyarakat miskin harus ke rumah sakit atau ke puskesmas, agar memperoleh nilai baik. Konotasinya, semakin banyak masyarakat miskin berkunjung ke rumah sakit atau ke puskesmas, maka inikator ini semakin bagus. Tindak lanjut yang dapat dilakukan untuk hal ini adalah perlu kesepakatan formulasi yang lebih realistis dan logis untuk beberapa indikator.

\section{4) Data Dasar}

Masalah yang sering muncul dari item ini adalah tidak semua data dasar tersedia dan data cenderung kurang update. Budaya data dan komitmen dengan data masih relatif kurang, sehingga perhitungan dan evaluasi terhadap implementasi SPM cenderung terhambat karenanya. SKPD dan instansi penyedia data cenderung kurang dapat menjadi penyuplai data. Tidak jarang, pengelola SPM sendiri yang harus mencari data, akibatnya energi dan waktu banyak tersita hanya untuk mencari dan mengelola data.

Contoh kasus terjadi di SPM Bidang Kesehatan. Jumlah kunjungan pasien miskin di Strata I dan jumlah Miskin di kota, jika merujuk pada DO maka agar capaian 100\% jumlah kunjungan setara 
dengan jumlah masyakarat miskin (Kegiatan promotif-preventif dianggap tidak berjalan karena semua masyarakat miskin merujuk pada DO perlu berkunjung ke Strata I). Tindak lanjut untuk kasus ini adalah, dengan adanya feedback terhadap permasalahan DO indikator tersebut maka saat ini data dasar kunjungan puskesmas ke rumah masyarakat miskin juga menjadi bagian pemenuhan definisi DO pada pembilang.

\section{5) Penetapan Target SPM}

Target SPM biasanya ditetapkan dalam Renstra SKPD dengan memperhatikan data dasar dan kemampuan SKPD yang mencerminkan ketersediaan keuangan dan sumberdaya yang ada. Target SPM juga memperhatikan target SPM nasional, sebagai pembanding dalam melakukan evaluasi SPM. Masalah akan muncul saat target SPM terlalu optimis, apalagi jika target nasional mensyaratkan untuk itu. Idealnya, penetapan target SPM melibatkan SKPD terkait seperti Bappeda dan atau instansi teknis lain yang terkait. Tujuannya adalah untuk mensinkronkan target dengan kemampuan sumberdaya baik personil maupun keuangan.

Penetapan target SPM yang terlalu merujuk kepada target SPM nasional, dapat mengakibatkan target menjadi terlalu optimis dan terlalu pesimis. Sebagai contoh, Wajib Belajar 9 Tahun sebagai Target Nasional pada bidang pendidikan, sebenarnya terlalu pesimis untuk karateristik kabupaten/kota di Kalimantan Timur. Idealnya adalah Wajib Belajar 12 Tahun. Sebaliknya, untuk indikator persentase pengurangan sampah perkotaan, yang target nasional menyebutkan angka 20\%, terlalu optimis untuk kabupaten/kota di Kalimantan Timur.

Dengan demikian idealnya penetapan target SPM sebaiknya dilakukan bersama-sama SKPD terkait, dan dilakukan sejak awal proses pembuatan dokumen perencanaan SPM. Proses verifikasi dan validasi Renstra yang memuat penetapan target SPM, harus dioptimalkan untuk memperoleh target SPM yang logis dan riil, tidak terlalu berat, dan tidak terlalu ringan.

\section{6) Perumusan Program dan Kegiatan}

Program dan kegiatan yang mendukung tercapainya target SPM, harus dikreasi dengan tidak melanggar Permendagri Nomor 13 Tahun 2006. Namun di sisi lain, program dan kegiatan juga harus mencantumkan pelaksanaan visi dan misi Kepala Daerah Terpilih. Tidak jarang janji politik kepala daerah, juga menyangkut indikator SPM. Dengan demikian diperlukan kreasi program yang secara formal tidak melanggar Permendagri Nomor 13 Tahun 2006, dan juga dapat mengakomodir visi dan misi kepala daerah.

Masalah yang muncul biasanya terjadi pada disharmoni RPJMD dan Renstra dengan Permendagri No. 13 Tahun 2006. Apalagi Permendagri yang dibuat pada Tahun 2006 ini, telah memiliki tingkat keusangan yang tinggi. Misalnya, dengan keluarnya UU Nomor 23 Tahun 2014 mengakibatkan terjadinya pergeseran kewenangan kabupaten/kota pada berbagai urusan wajib dan urusan pilihan. Artinya, diperlukan usaha keras untuk mengharmonisasikan program-program yang dibuat dalam RPJMD dan Renstra dikaitkan dengan program dan kegiatan yang dikreasi khusus untuk mengimplementasikan SPM.

\section{7) Anggaran}

Idealnya pembiayaan program dan kegiatan yang terkait dengan SPM menjadi prioritas. Namun, anatomi pembiayaan dalam APBD lebih mengutamakan kepada pembiayaan yang wajib dan mengikat. Sehingga sering muncul keluhan, SKPD diberi tugas mencapai SPM, namun anggaran terlalu kecil untuk mencapai target itu. Mencermati anatomi APBD kabupaten/kota, SKPD pelaksana SPM sebenarnya sudah diberikan dana yang cukup besar, semisal Pekerjaan Umum yang biasanya memiliki pembiayaan berkisar 20-30\% dari APBD. Demikian pula dengan Dinas Pendidikan, telah dipatok harus memiliki anggaran pembiayaan sebesar 20\%. Namun diluar dari 2 SKPD, masih relatif kecil seperti Dinas Kesehatan yang hanya memiliki anggaran berkisar 5-8\%. Apalagi untuk Dinas Sosial atau Satpol PP yang lebih kecil dari pada anggaran pembiayaan 2 dinas yang disebutkan di awal.

Khusus untuk Dinas Pendidikan, meski anggaran relatif besar, mencapai 20\%, namun anggaran sebesar itu sebagian digunakan untuk belanja wajib dan mengikat seperti pembayar gaji dan honor, serta insentif guru yang jumlahnya juga banyak. Padalah dalam semangat mencapai target SPM, anggaran pendidikan sebesar $20 \%$, idealnya diperuntukan untuk pelaksanaan dan pelayanan pendidikan dasar. 


\section{8) Integrasi SPM dalam Dokumen Perencanaan}

SPM harus dan wajib diintegrasikan kedalam seluruh dokumen, dimulai dari RPJMD dan Renstra, RKPD dan Renja, serta dokumen perencanaan derivatif lainnya di pemerintah daerah maupun di SKPD. Saat pembuatan dokumen perencanaan ini, terdapat proses sinkronisasi antar dokumen, baik dalam bentuk Konsultasi Publik, maupun dalam bentuk verifikasi dokumen perencanaan yang lebih rendah tingkatnya ke dokumen perencanaan yang lebih tinggi. Namun, kadang proses sinkronisasi ini kurang berjalan optimal, mengingat waktu yang terlalu sempit dan atau, pejabat yang melakukan sinkronisasi bukanlah pejabat yang dapat mengambil kebijakan. Tidak jarang wakil SKPD yang hadir hanyalah staf biasa yang tidak dapat mengambil keputusan strategis dalam perencanaan.

Integrasi SPM kedalam dokumen perencanaan juga menjadi kurang terlaksana mengingat waktu pembuatan dokumen terlalu sempit. RPJMD misalnya, hanya memiliki waktu pembuatan selama 6 bulan sejak kepala daerah dilantik. Akibatnya, gap antar dokumen perencanaan masih terlalu lebar. Bappeda sebagai SKPD penanggungjawab pembuatan perencanaan, kadang juga dibebani tugas dan fungsi yang berat, mengingat badan ini harus mengkoordinir perencanaan di SKPD lain yang satu level dengannya.

Integrasi antar SPM dengan dokumen perencanaan, dapat lebih ptimal dilaksanakan, jika komitmen seluruh SKPD cukup kuat. Tentu saja harus dibarengi dengan perhatian lebih dari kepala daerah. Kota Balikpapan dapat menjadi contoh komitmen kepala daerah yang kuat, saat peneliti melakukan observasi ke kota ini. Walikota atau wakil walikota tidak segan untuk berkomunikasi langsung dengan SKPD, dengan intensitas hampir setiap hari, untuk mengawasi pembuatan perencanaan, agar sinkron dengan tupoksi SKPD, termasuk SKPD pelaksana SPM.

\section{9) Koordinasi antar Stakeholder Daerah}

Kondisi ego-sektoral yang kuat, masih mejadi salah satu titik lemah koordinasi antar SKPD dalam pelaksanaan SPM. Sebagai contoh, pembangunan sarana-prasarana, apakah menjadi tugas PU atau menjadi tugas instansi teknis lainnya, semisal jalan usaha tani yang selintas nampak menjadi tugas Dinasi Pertanian. Contoh lain adalah Rumah Layak Huni, yang juga menjadi indikator SPM yang di daerah masih tarik ukur antara satu SKPD dengan SKPD lainnya.

Masalah lain yang terkait dengan koordinasi adalah dalam hal pengerjaan proyek untuk memenuhi indikator SPM, dibutuhkan koordinasi lintas instansi. Sebagai contoh untuk memenuhi indikator tersedianya air baku untuk memenuhi kebutuhan pokok minimal sehari hari, Dinas Pekerjaan Umum harus berkoordinasi dengan PDAM, Badan Lingkungan Hidup, dan Bappeda. Contoh lain lagi, untuk memenuhi indikator tersedianya pedoman harga standar bangunan gedung negara, Dinas Pekerjaan Umum harus berkoordinasi dengan Badan Pengelola Keuangan dan Aset Daerah. Koordinasi lintas instansi tersebut tidak mudah dilakukan, terkadang perbedaan persepsi diantara instansi menjadi penghambat pencapaian SPM.

Solusi yang ditawarkan untuk menutupi kelemahan ini adalah dengan meningkatkan koordinasi antara SKPD pelaksana SPM, dan dituangkan dalam dokumen perencanaan. Penentuan Indikator Kinerja Daerah (IKD) dan Indikator Ikerja Khusus (IKK) dapat menjadi instrumen yang baik, untuk menetapkan penanggung jawab indikator SPM yang tertuang dalam dokumen perencanaan.

\section{0) Pembinaan dari Kementerian dan Kelembagaan}

Pembinaan tentang SPM baik dari Kmenterian dan Kelembagaan, bukan idak pernah dilakukan. Namun frekuensi dan rutinitasnya belum terjaga. Di samping itu, pembinaan yang sering dilakukan kementerian masih belum dapat menjawab secara tuntas masalah-masalah yang dihadapi oleh SKPD pelaksana SPM. Sebagai contoh kasus, indikator Cakupan Pelayanan Kesehatan Dasar Masyarakat Miskin, dan Cakupan Pelayanan Kesehatan Rujukan Masyarakat Miskin, saat didiskusikan ke kementerian, belum dapat dituntaskan, seperti apa solusinya. Demikian pula kesimpangsiuran definisi operasional pada beberapa indikator SPM, masih belum dapat dituntaskan.

Solusi untuk masalah ini adalah SKPD pelaksana SPM idealnya pro aktif dan rajin untuk berkomunikasi dengan Kementerian yang menangani SPM. Berbagai masalah dapat ditanyakan dan didiskusikan secara interaktif. Biasanya cara ini sangat efektif untuk menanggulangi masalah-masalah SPM, dibanding 
menunggu peraturan atau kebijakan baru, yang akibat birokrasi, sering terlambat diketahui dan disosialiasikan pihak kementerian.

\section{SIMPULAN}

adalah:

Beberapa kesimpulan yang dapat diambil dalam penelitian ini, mengacu dari hasil penelitian

1) Pelaksanaan SPM di Kabupaten/Kota Provinsi Kalimantan Timur secara umum telah melalui berbagai proses dan dilaksanakan sesuai dengan peraturan perundangan yang berlaku. Di beberapa daerah selain Undang-undang dan peraturan dari kementerian, juga telah dilengkapi dengan Peraturan Daerah, untuk melengkapi landasan dan dasar pelaksanaan SPM di beberapa bidang dan SKPD pelaksana SPM.

2) Capaian Pelaksanaan SPM di Kabupaten/Kota Provinsi Kalimantan Timur, pada umumnya telah tercapai. Berdasarkan bidang dan jenis SPM, maka pendidikan dan kesehatan adalah bidang yang paling banyak mencapai target, dari sekumpulan indikator yang tertera dalam SPM. Bidang lainnya seperti PU dan Tata Ruang, Pemukiman dan Tata Kota, dan Sosial, tingkat capaiannya cenderung lebih rendah dari capaian dua bidang yang disebutkan terdahulu.

3) Meski secara umum target SPM telah tercapai, namun tingkat keefektifan capaian SPM jika dibandingkan dengan target nasional, masih menjadi titik lemah. Pendidikan dan Kesehatan kembali menjadi bidang SPM yang paling efektif. Sementara bidang lainnya, cenderung bervariasi pada setiap kabupaten/kota.

4) Berbagai kendala dan permasalahan pelaksanaan dan pencapaian target SPM adalah:

a) Tingkat pemahaman SPM yang belum komprehensif

b) Tidak semua indikator dan definisi operasional dalam SPM mudah dipahami dan sesuai dengan karakteristik daerah

c) Terdapat beberapa formulasi indikator SPM yang kurang faktual dan kurang logis

d) Data dasar yang kurang tersedia dan kurang update

e) Penetapan target yang kurang tepat

f) Kreasi program dan kegiatan dalam perencanaan, serta anggaran yang kurang berpihak kepada SPM

g) Integrasi SPM kedalam dokumen yang masih belum optimal

h) Ego-sektoral antar SKPD pelaksana SPM yang masih kuat, sehingga melemahkan koordinasi antar SKPD.

i) Pembinaan SPM dari kementerian yang belum rutin dan kontinyu

\section{SARAN}

adalah:

Beberapa saran yang ditawarkan dalam penelitian ini, agar pelaksanaan SPM dapat lebih efektif

1) Pemerintah Pusat

a) Perlu peningkatan koordinasi dan sinkronisasi yang lebih intensif antar Kementerian Dalam Negeri dengan kementerian lainnya yang terkait dengan SPM, untuk mengeliminir saling tumpang tindihnya peraturan dan kebijakan tentang SPM, serta mengurangi kesimpangsiuran indikator SPM.

b) Pemerintah pusat secara aktif dan kontinyu dapat melakukan sosialisasi kepada daerah untuk pendalaman pemahaman tentang SPM.

c) Daerah perlu diberikan ruang untuk menetapkan dan menerapkan SPM yang sesuai dengan karakteristik daerahnya.

d) Pemerintah pusat perlu mendampingi pemerintah daerah dalam penyusunan profil pelayanan dasar di daerah

2) Pemerintah Daerah

a) Perlu pengembangan kapasitas personil SKPD pelaksana SPM dalam rangka menyusun Rencana Aksi Daerah (RAD)

b) Perlu peningkatan komitmen pimpinan (kepala SKPD dan kepala daerah) dalam pelaksanaan dan penerapan SPM, termasuk komitmen anggaran dan pembiayaan 
c) Pemerintah daerah seyogyanya proaktif berhubungan dengan Kementerian dalam Negeri dan Kementerian lainnya terkait dengan petunjuk teknis pelaksanaan SPM

d) Pemerintah daerah perlu menempatkan personil pelaksana SPM yang sesuai dengan keahliannya, dan memberikan waktu yang cukup untuk personil tersebut, untuk mengembangkan dirinya, mendalami SPM secara komprehensif.

e) Pemerintah daerah perlu meningkatkan komitmen tentang budaya data, termasuk memotivasi personil pelaksana SPM untuk selalu bekerja dengan data yang lengkap dan up date.

Pemerintah daerah perlu memotivasi peningkatan komitmen lintas SKPD untuk mengurangi kuatnya kondisi ego-sektoral antar SKPD.

\section{DAFTAR PUSTAKA}

\section{Artikel Jurnal dan Internet}

Artikel "Nilai Strategis Penerapan Standar Pelayanan Minimal”, Jendela Pembangunan Daerah, Edisi 5 Maret - 5 April 2016, Tahun VII, hlm. 9.

Artikel "Percepatan Standar Pelayanan Minimal di Daerah", diakses dari http://otda.kemendagri.go.id/index.php/berita-210/1383-percepatan-standarpelayanan-minimal-di-daerah, pada hari jumat 13 Mei 2016, jam 21.46 Wita.

Kementerian Dalam Negeri (2012) yang dikutip dari website http://dataaparatur.bandung.lan.go.id/index.php?r=isiDataKetatalaksanaan/dataKetatal aksanaanView\&tabel=142\&year=2016, diakses pada hari jumat 13 Mei 2016, jam 22.00 Wita.

Kushandajani, "Standar Pelayanan Minimal (SPM) dan Peningkatan Pelayanan Publik di Era Otonomi Daerah", eprints.undip.ac.id.

Muhammad Roudo dan Asep Saipudin, "Meningkatkan Pelayanan Publik Melalui Penyusunan dan Penerapan Standar Pelayanan Minimal (SPM): Konsep, Urgensi, dan Tantangan", Riptek, Vol.2 No.1, Tahun 2008, hlm.4.

\section{Peraturan Perundang-undangan}

Undang-Undang Nomor 23 Tahun 2014 tentang Pemerintahan Daerah sebagaimana terakhir kalinya diubah dengan Undang-Undang Nomor 9 Tahun 2015 tentang Perubahan Kedua Atas Undang-Undang Nomor 23 Tahun 2014 tentang Pemerintahan Daerah.

Peraturan Pemerintah Republik Indonesia Nomor 65 Tahun 2005 tentang Pedoman Penyusunan Dan Penerapan Standar Pelayanan Minimal.

Peraturan Menteri Dalam Negeri Nomor 6 Tahun 2007 tentang Petunjuk Teknis Penyusunan Dan Penetapan Standar Pelayanan Minimal, dan Peraturan Menteri Dalam Negeri Nomor 79 Tahun 2007 tentang Pedoman Penyusunan Rencana Pencapaian Standar Pelayanan Minimal.

Peraturan Menteri Perumahan Rakyat RI No. 22/PERMEN/M/2008 tentang Standar Pelayanan Minimal bidang Perumahan Rakyat daerah Provinsi dan daerah Kabupaten/Kota.

Peraturan Menteri Dalam Negeri RI Nomor 62 Tahun 2008 tentang Standar Pelayanan Minimal Bidang Pemerintahan Dalam Negeri di Kabupaten/Kota sebagaimana diubah dengan Permendagri Nomor 69 Tahun 2012 Tentang Perubahan Atas Peraturan Menteri Dalam Negeri Nomor 62 Tahun 2008 Tentang Standar Pelayanan Minimal Bidang Pemerintahan Dalam Negeri Di Kabupaten/Kota.

Peraturan Menteri Sosial RI Nomor 129/HUK/ 2008 Tentang Standar Pelayanan Minimal (SPM) Bidang Sosial Daerah Provinsi Dan Daerah Kabupaten/Kota dan Keputusan Menteri Sosial Republik Indonesia Nomor 80/HUK/2010 tentang Panduan Perencanaan Pembiayaan Pencapaian Standar Pelayanan Minimal (SPM) Bidang Sosial Daerah Provinsi dan Daerah Kabupaten/Kota.

Peraturan Menteri Kesehatan RI Nomor 741/MENKES/Tahun 2008 Tentang Standar Pelayanan Minimal Bidang Kesehatan di Kabupaten/Kota. 
Peraturan Menteri Dalam Negeri RI Nomor 44 Tahun 2010 tentang Ketentraman dan Perlindungan Masyarakat Dalam Rangka Penegakan Hak Asasi Manusia.

Peraturan Menteri Pendidikan dan Kebudayaan RI Nomor 23 Tahun 2013 Tentang Perubahan Atas Peraturan Menteri Pendidikan Nasional Nomor 15 Tahun 2010 Tentang Standar Pelayanan Minimal Pendidikan Dasar di Kabupaten/Kota.

Peraturan Menteri Negara PU RI Nomor 01 Tahun 2014 tentang Standar Pelayanan Minimal Bidang Pekerjaan Umum dan Penataan Ruang Kabupaten/Kota.

Keputusan Menteri Kesehatan RI Nomor 828/MENKES/SK/IX/2008 Tentang Petunjuk Teknis Standar Pelayanan Minimal Bidang Kesehatan Di Kabupaten/Kota

Keputusan Menteri Sosial Republik Indonesia Nomor 80/HUK/2010Tentang Panduan Perencanaan Pembiayaan Pencapaian Standar Pelayanan Minimal (SPM) Bidang Sosial Daerah Provinsi dan Daerah Kabupaten/Kota 